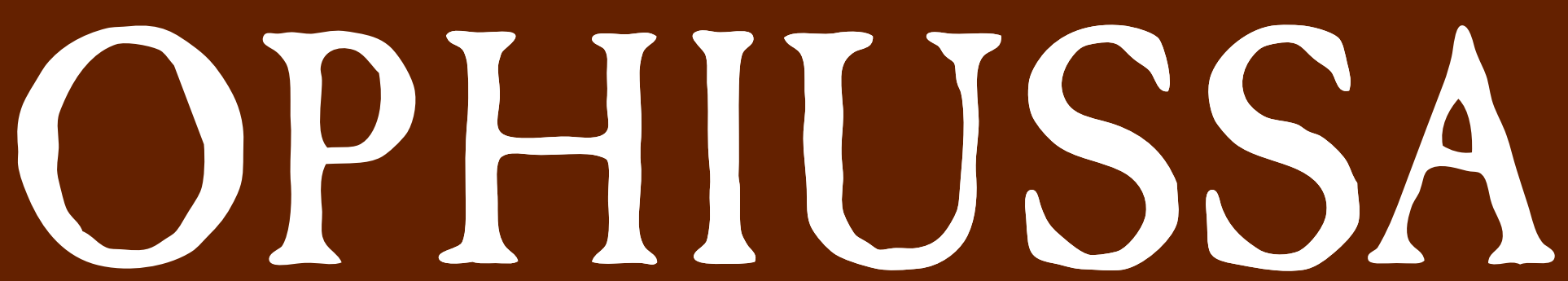

REVISTA DO CENTRO DE ARQUEOLOGIA DA UNIVERSIDADE DE LISBOA

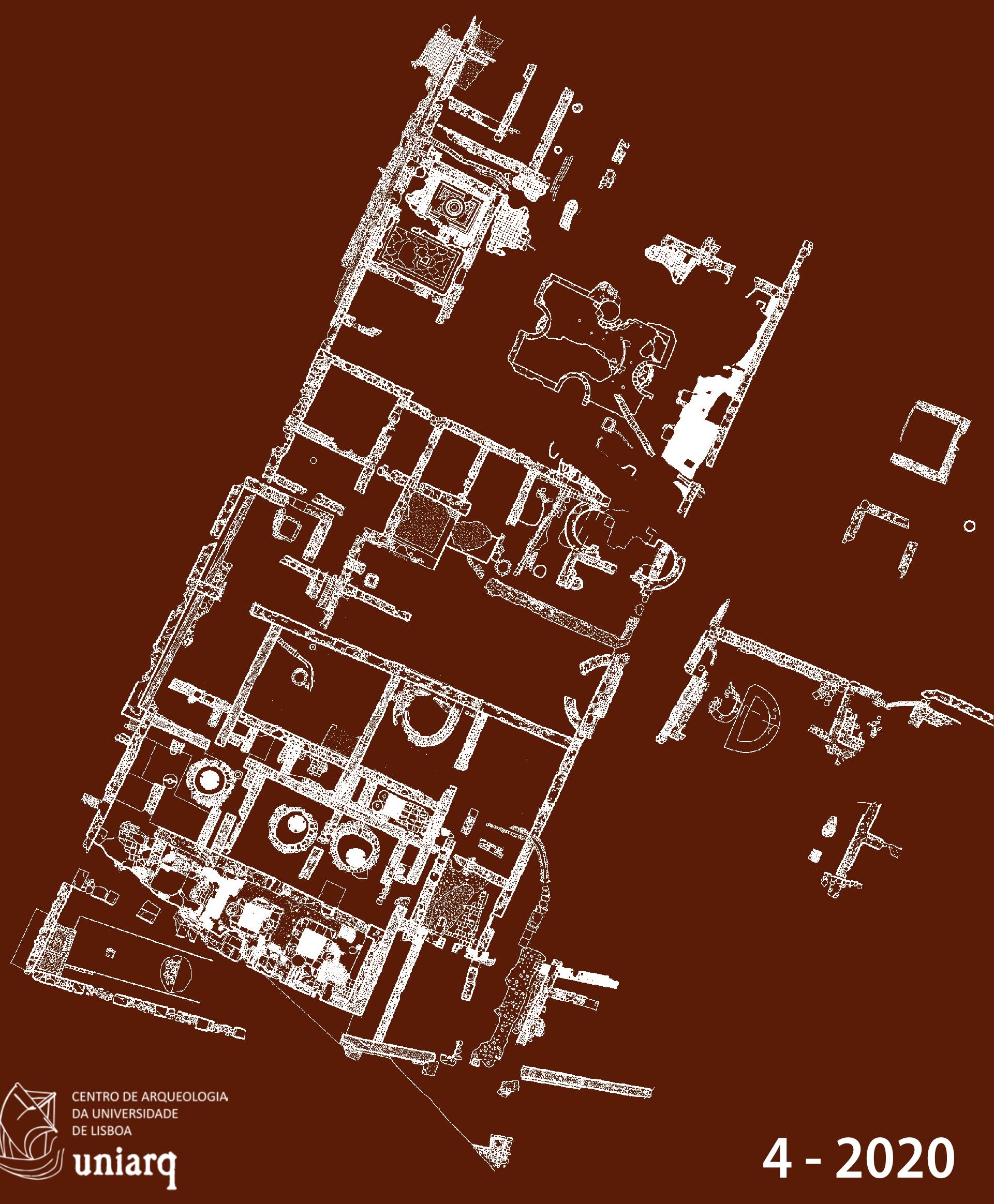




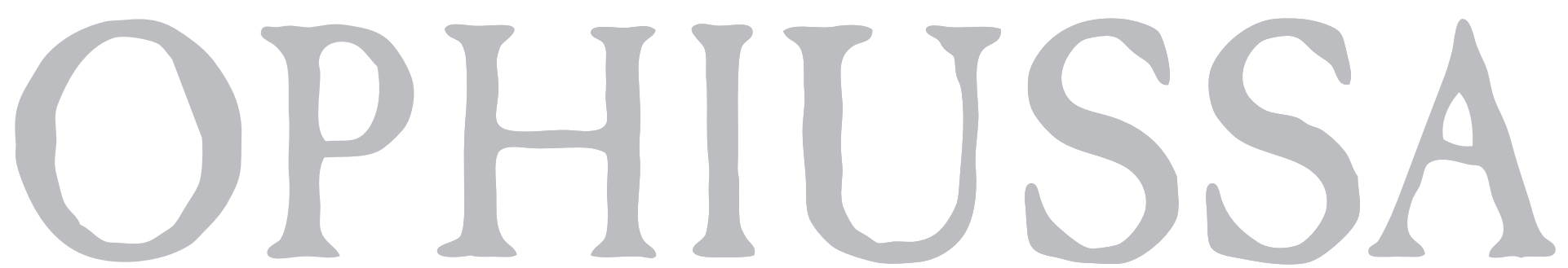

REVISTA DO CENTRO DE ARQUEOLOGIA DA UNIVERSIDADE DE LISBOA

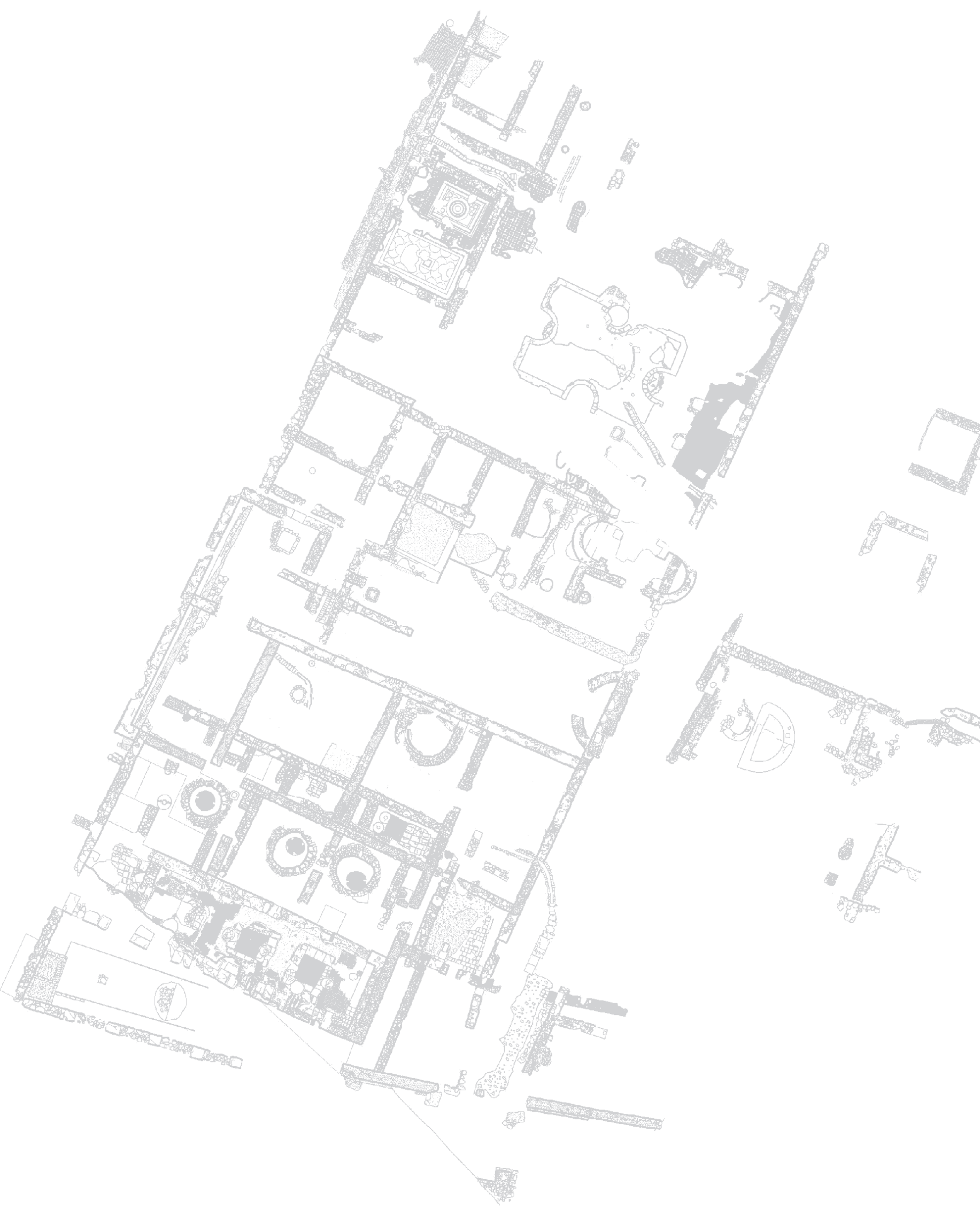




\section{U IISBOA \\ UNIVERSIDADE

\section{OPHIUSSA REVISTA DO CENTRO DE ARQUEOLOGIA DA UNIVERSIDADE DE LISBOA}

PUBLICAÇÃO ANUAL · ISSN 1645-653X · E-ISSN 2184-173X

Volume 4 - 2020

DIRECÇÃO E COORDENAÇÃO EDITORIAL

Ana Catarina Sousa

Elisa Sousa

\section{CONSELHO CIENTÍFICO}

André Teixeira

UNIVERSIDADE NOVA DE LISBOA

Carlos Fabião

UNIVERSIDADE DE LISBOA

Catarina Viegas

UNIVERSIDADE DE LISBOA

Gloria Mora

UNIVERSIDAD AUTÓNOMA DE MADRID

Grégor Marchand

CENTRE NATIONAL DE LA RECHERCHE SCIENTIFIQUE

João Pedro Bernardes

UNIVERSIDADE DO ALGARVE

José Remesal

UNIVERSIDADE DE BARCELONA

Leonor Rocha

UNIVERSIDADE DE ÉVORA

Manuela Martins

UNIVERSIDADE DO MINHO

Maria Barroso Gonçalves

INSTITUTO SUPERIOR DE CIENNCIAS DO TRABALHO E DA EMPRESA)

Mariana Diniz

UNIVERSIDADE DE LISBOA

Raquel Vilaça

UNIVERSIDADE DE COIMBRA

Victor S. Gonçalves

UNIVERSIDADE DE LISBOA

Xavier Terradas Battle

CONSEJO SUPERIOR DE INVESTIGACIONES CIENTÍFICAS

\section{SECRETARIADO}

André Pereira

CAPA

Julia Rodríguez Aguilera

(Gespad al Andalus)
REVISOR DE ESTILO

Francisco B. Gomes

PAGINAÇÃo

TVM Designers

IMPRESSÃO

AGIR - Produções Gráficas

DATA DE IMPRESSÃO

Dezembro de 2020

EDIÇÃO IMPRESSA (PRETO E BRANCO)

300 exemplares

EDIÇÃO DIGITAL (A CORES)

www.ophiussa.letras.ulisboa.pt

ISSN 1645-653X / E-ISSN 2184-173X

DEPÓSITO LEGAL 190404/03

Copyright $\odot 2020$, os autores

EDIÇÃO

UNIARQ - Centro de Arqueologia

da Universidade de Lisboa,

Faculdade de Letras de Lisboa

1600-214 Lisboa.

www.uniarq.net

www.ophiussa.letras.ulisboa.pt

uniarq@letras.ulisboa.pt

Revista fundada por Victor S. Gonçalves (1996). O cumprimento do acordo ortográfico de 1990 foi opção de cada autor.

Esta publicação é financiada por fundos nacionais através da FCT - Fundação para a Ciência e a Tecnologia, I.P., no âmbito do projecto UIDB/00698/2020. 
ÍNDICE

The megalithic clusters of Deserto and Barrocal das Freiras

(Montemor-o-Novo, Middle Alentejo) in the building of the sacred

landscapes of ancient peasant societies of the $4^{\text {th }}$ and $3^{\text {rd }}$ millennia BCE

VICTOR S. GONÇALVES, MARCO ANTÓNIO ANDRADE

From aDNA to Archaeology: Genética da transição Calcolítico-Idade do Bronze

no Sul de Portugal

ANA CATARINA BASÍLIO

Foundry in the Late Bronze Age Baiões/Santa Luzia Cultural Group:

some reflections starting from a new metallic mould for unifacial palstaves

JOÃO CARLOS SENNA-MARTINEZ, PEDRO VALÉRIO, MARIA HELENA CASIMIRO,

LUÍS M. FERREIRA, MARIA DE FÁTIMA ARAÚJO, HORÁCIO PEIXOTO

O conjunto vítreo da necrópole da I Idade do Ferro da Fonte Velha

de Bensafrim (Lagos)

FRANCISCO B. GOMES

Espacios de almacenamiento y producción de la Turdetania.

Una reflexión más allá de los hornos

VIOLETA MORENO MEGÍAS

Os três sarcófagos etruscos da colecção de Sir Francis Cook

no Museu Arqueológico de São Miguel de Odrinhas (Sintra)

MARTA RIBEIRO, NUNO SIMÕES RODRIGUES

Nuevos datos para el conocimiento del suburbium del Municipum

Florentinum Iliberritanum (Granada): las recientes intervenciones

en el solar de Mondragones

ÁNGEL RODRÍGUEZ AGUILERA, MACARENA BUSTAMANTE-ÁLVAREZ,

JULIA RODRÍGUEZ AGUILERA, CARMEN JÓDAR HÓDAR, JOSÉ M. GARCÍA-CONSUEGRA FLORES

Mapear a bibliografia. Abordagem metodológica para a gestão

de dados bibliográficos

NATÁLIA BOTICA, SÍLVIA MACIEL, REBECA BLANCO-ROTEA

Recensões bibliográficas

(TEXTOS: JORGE DEL REGUERO GONZÁLEZ, LUIS MIGUEL CARRANZA PECO,

MARTA BERMÚDEZ CORDERO, ÁLVARO GÓMEZ PEÑA, ANDRÉ TEXUGO)

Da CAALG à UNIARQ: a génese do Centro de Arqueologia da Universidade

de Lisboa no quadro do sistema científico de meados dos anos 70

a meados dos anos 90 do século XX

ANDRÉ PEREIRA

Avaliadores Ophiussa (2018-2020) 


\title{
Foundry in the Late Bronze Age Baiões/Santa Luzia Cultural Group: some reflections starting from a new metallic mould for unifacial palstaves
}

\author{
A fundição no Mundo Baiões/Santa Luzia: \\ algumas reflexões partindo de um novo molde \\ metálico para machados de talão unifaciais
}

\author{
JOÃO CARLOS SENNA-MARTINEZ \\ Centro de Arqueologia (Uniarq) da Universidade de Lisboa \\ smartinez@fl.ul.pt \\ PEDRO VALÉRIO, MARIA HELENA CASIMIRO, LUÍS M. FERREIRA, MARIA DE FÁTIMA ARAÚJO \\ Centro de Ciências e Tecnologias Nucleares (C2TN), Instituto Superior Técnico, Universidade de Lisboa \\ HORÁCIO PEIXOTO \\ EAM - Associação Para o Estudo Arqueológico da Bacia do Mondego. \\ Canas de Senhorim
}

ABSTRACT: During the last quarter of a century, progress on the understanding of metallurgical practices of the Baiões / Santa Luzia cultural group of Central Portugal produced results that allowed us to better understand and characterize a fundamental cultural group of the Iberian Late Bronze Age (LBA). However, the study of the foundry moulds lacks a convenient interpretive synthesis.

The discovery of a new exemplar of metallic mould for single-faceted palstaves - one of the types that characterize Central Portugal LBA metallurgy - creates the opportunity to, starting with its archaeometallurgical characterization, produce an overview of Baiões / Santa Luzia moulds and foundry procedures, namely for the palstaves moulds that, until now, are mostly known in the area of this cultural group.

KEY WORDS: Archaeometallurgy; Foundry moulds; Baiões / Santa Luzia cultural group; Late Bronze Age.

RESUMO: Os progressos efectuados nos últimos vinte anos sobre a metalurgia do Grupo Baiões/Santa Luzia do Bronze Final do Centro de Portugal trouxeram novidades importantes que permitiram conhecer melhor um grupo cultural fundamental para a caracterização do Bronze Final Peninsular. Contudo, o estudo dos moldes de fundição aí identificados carece de síntese interpretativa conveniente.

A descoberta de um novo exemplar de molde metálico para machados de talão unifaciais, um dos tipos caracterizadores do Bronze Final do Centro de Portugal, veio criar a oportunidade para, partindo da sua caracterização arqueometalúrgica, avançar com uma visão de conjunto dos moldes e processos de fundição no mundo Baiões/Santa Luzia, nomeadamente no caso dos moldes de machados de talão, até ao momento maioritariamente conhecidos na área deste grupo cultural.

PALAVRAS-CHAVE: Arqueometalurgia; Moldes de fundição; Grupo Baiões/Santa Luzia; Bronze Final. 


\section{IN THE BEGINNING...}

In different historical moments (in the widest sense), the Portuguese "Beiras" (Fig. 1) constitute an almost unavoidable transit area between Portugal northern and south-central regions on one hand and the Spanish Northern Meseta on the other. Thus, these interior areas function as a connecting plate between those regions, fundamental to the understanding of the interregional interaction and integration processes that are going on during the Prehistory of Peasant Societies (from Early Neolithic to the Late Bronze Age - LBA), and particularly during the LBA (Senna-Martinez 1999: 45; 2013a; 2013b; 2013c).

One of us already wrote that "...The main transformation suffered by LBA studies in Portugal during the last two decades [of the $20^{\text {th }}$ century] consists of a change in approach from metal hoards to finding and excavating habitat sites, studying their material culture, economic indicators and spatial location..." (Senna-Martinez - Pedro 2000a: 61).

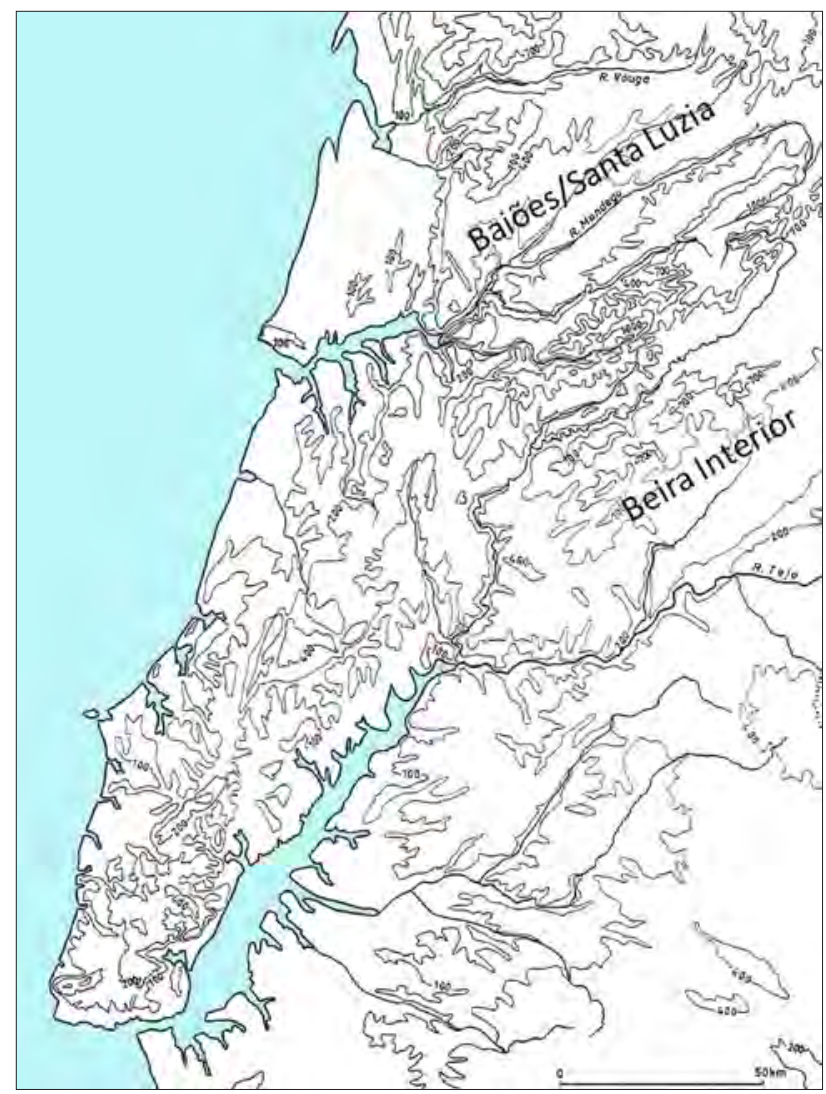

FIG. 1 Central Portugal Oro-Hydrography. The coastline reproduces the maximum of the Flandrian transgression. Superimposed are the two culture areas central to the paper the Baiões/Santa Luzia and the Beira Interior ones.
This development of research strategies - that kept going on till the present - led to parallel progress on the understanding of the respective metallurgical practices, namely for the Central Portugal Baiões/Santa Luzia LBA cultural group (Senna-Martinez et al. 2011). This last quoted paper presents the results of an FCT project ${ }^{1}$ developed between 2006 and 2009 that allowed us to better understand and characterize this fundamental cultural group of the lberian LBA.

Foundry technology was one of the project concerns but we lacked a comprehensive study of the moulds for artefact casting belonging to this cultural group (Senna-Martinez - Pedro 2000a: 63). We try here to produce it, recently motivated by the discovery of a new exemplar of a bronze mould for the production of unifacial palstaves, the second one we know from the area of this cultural group and, indeed, for all Western Iberia.

\section{GEOGRAPHICAL AND GEOLOGICAL SETTING}

The interior basins of the Mondego and Vouga rivers, as well as part of the Alto Paiva basin which constitute the heart of the Beira-Alta region are the home of LBA Baiões / Santa Luzia Culture Group (Fig. 1) (Senna-Martinez 1994).

The Portuguese central highlands, the Serras of Lousã, Açor and Estrela, are part of the Iberia central divide and make the southern limits of Beira-Alta. Serra da Estrela, in particular, has very good spring and summer pastures that seem to have been in use since the Neolithic (Knaap - Van Leeuwen 1994; Senna-Martinez - Ventura 2008). Separation of the Mondego and Vouga interior basins from the coastal lowlands is marked by another highland system, the Maciço Marginal. Coming from the south and going around the Serra do Caramulo the middle Mondego basin opens up to the Vouga and Paiva rivers' upper basins, these support two natural passageways going respectively West and North. Westwards, the Vouga crossing of the Maciço Marginal is controlled by the Castro da Senhora da Guia de Baiões (CSGB), a very important

The METABRONZE project (Metallurgy and Society in Central Portugal Late Bronze Age - POCTI/HAR/58678/2004) was developed between 2006 and 2009 and was financed by the Portuguese Foundation for Science and Technology (FCT). 
Late Bronze Age settlement which was at the core of METABRONZE Project.

East and north of the Celorico basin, the northern Meseta step divides Beira-Alta from the north-central Iberia. Nevertheless it allows transit through several natural paths that, during the Middle Age, were defended by several medieval castles established at both sides of the border zone with Castilla.

North of our study area, the high basins of the Paiva and the Távora link it to the Douro basin thus both allowing and explaining cultural contacts.

For the period under consideration the principal vegetation cover seems to have been a deciduous temperate oak forest (Quercus pyrenaica at altitudes over 600-800 m and Quercus robur at lower altitudes - cf. Janssen - Woldringh 1981; Janssen 1985; van den Brink - Janssen 1985; Knaap - van Leeuwen 1994).

In the last quarter of the $20^{\text {th }}$ century a program of peat coring in lagoons, following a roughly north-south transect of Serra da Estrela, allowed palynological analyses that supported a model for the Holocene evolution of the vegetation cover for the Serra and its surroundings (Janssen 1985; Knaap - van Leeuwen 1994). The proposed model implied several episodes of degradation of the Holocene climatic optimum reconstructed oak forest, attributed to human impact. The several degradation phases seem to be marked by deliberate human provoked deforestation and bush fires at middle and high altitudes of Serra da Estrela, probably with the intention of opening of spring-summer grazing lands.

Contrary to what we came to suppose (Senna-Martinez 1995-1996), a chronology of the fifth millennium $B C$ for a first episode of deforestation, resulting in "... general forest lightening, but with few and scattered clearings ..." (Knaap - Janssen 1991), correlate well with new evidence available for the regional Early Neolithic (Senna-Martinez - Ventura 2008).

A main episode about 3500 BC can well be correlated with the principal phase of development of the Neolithic megalithic necropolis (Senna-Martinez - Ventura 2008; Ventura 2018). If we accept the idea that the emergence of formal areas for the deposition of the dead frequently correlates with periods of imbalance between society and the critical resources available (Chapman 1981: 80), these resources would be related to the respective winter territories, since, for obvious reasons and in a perspective of long historical duration, thus encompassing the LBA, winter is the regional "low season" in terms of accessibility of food resources.

For the LBA, the deforestation process shows another intensification episode (Janssen 1985) in correlation with a later phase of the period (c. 1000-500 BC).

Old paths, some of them subsequently followed by the Roman roads (Alarcão 1988: 102-105 and Fig. 20), surely criss-crossed the country. However, the principal access to our study area if someone comes from the lower Mondego and littoral plains must have been the river basins until very recent times (Martins 1940: 164-166; Oliveira 1972: 1-5).

Talking about river navigability in our study period we must consider that, accordingly to our current knowledge, following a quick transgression in Early Holocene times (c.10000-8000 BP; Dias 1987: 330), the sea level stabilised near its present situation, invading deeply the lower river valleys (Daveau 1980: 24) between 5000-3000 BP (Dias 1987: 334).

The Mondego and Vouga flandrian paleoestuaries can be reconstructed, as a close enough estimation, and in broad lines, for the period under study, clearly establishing their importance as waterways to access the more inland areas (Fig. 1). In this way, the location of lower Mondego LBA sites and especially of the Phoenician "port of trade" of Santa Olaia becomes significant in terms of their possible relations with the ones in our study area.

Abundant mineral resources in tin and gold are part of Beira Alta probable attractiveness for the establishment of LBA populations (Garcia 1963; Senna-Martinez - Garcia - Rosa 1984: 117-118 and Fig. 2; cf. Senna-Martinez 2005: Fig. 1). Nevertheless old mines are difficult to find namely because most of the mining of these two resources would occur in alluvial placers (Comendador et al. 2014; 2017). A tiny window into past mining is otherwise known: the reopening, during World War Two, of the ancient gallery of the S. Martinho mine (Orgens, Viseu) led to the discovery, at the bottom of the rubble which filled its shaft, of a bronze dagger of "Porto de Mós type", proving its original opening and posterior infilling during the Late Bronze Age, probably for cassiterite exploitation (Correia - Silva - Vaz 1979). 

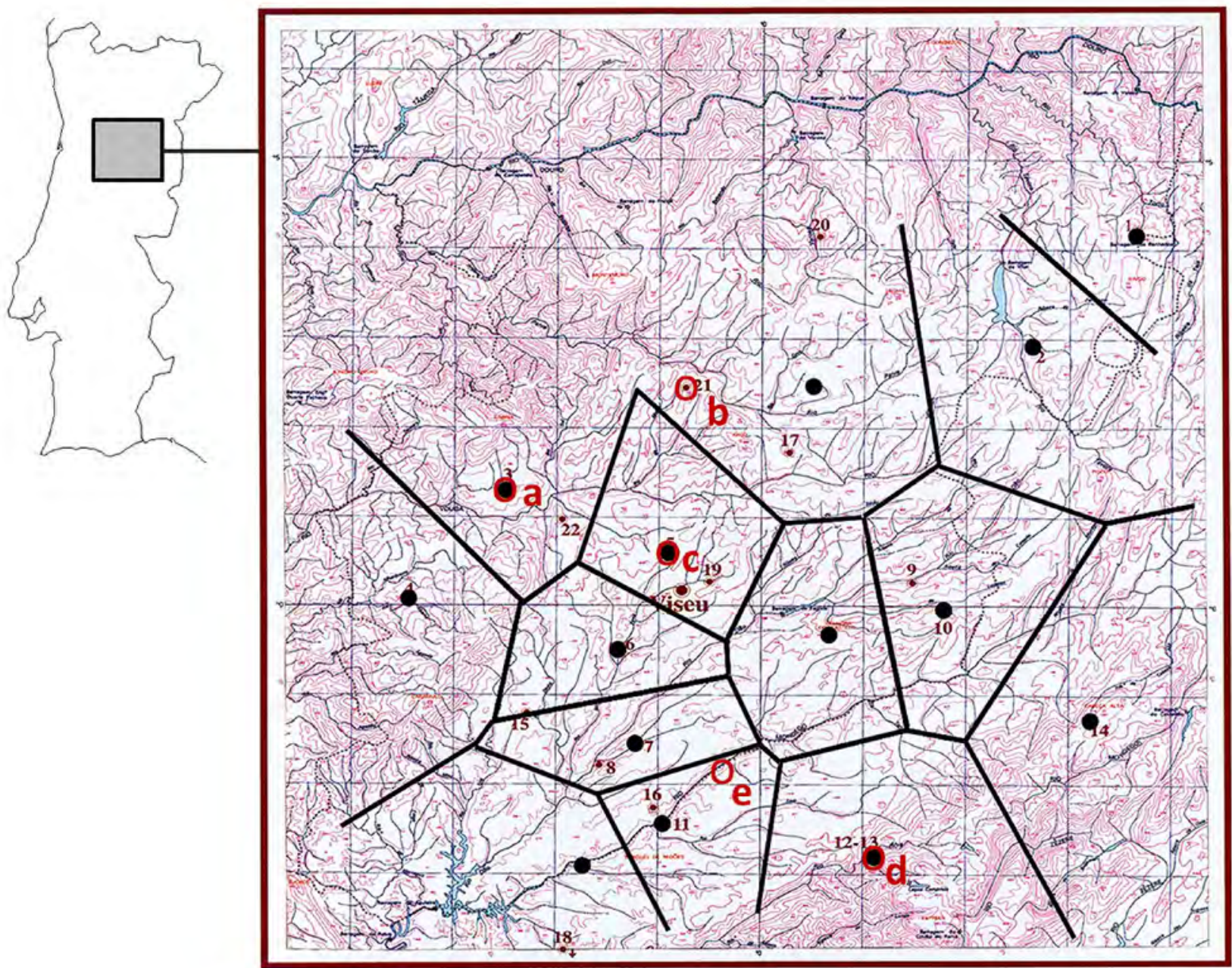

0 $30 \mathrm{~km}$

FIG. 2 Baiões / Santa Luzia central places network. Top- in Portugal. Bottom- the sites with moulds remains: a - Castro da Senhora da Guia de Baiões; b - Castro d'Aire; c - Castro de Santa Luzia; d- Cabeço do Crasto de S. Romão; e - Cabeço do Cucão da Pedra Cavaleira.

We must consider, however, that for binary bronze production "it takes two for tango". In the present case the second element is copper and it is an entirely different question from tin.

During the last two centuries it was thought that the main and almost only prehistoric sources for copper ores in the Iberian Peninsula come from its southern regions. If this is true in terms of modern industrial exploitation, it becomes an incorrect assumption in what concerns the early metallurgies of the Copper and Bronze Ages. For early metallurgical endeavors in Iberia almost any small outcrop with secondary mineralization of copper carbonates and / or oxides would do as a source at the scale these endeavors were practiced (Senna-Martinez 2013b). This was recently proven possible in the case of the Middle Bronze Age
(MBA) habitat site of Fraga dos Corvos (Macedo de Cavaleiros, Trás-os-Montes - Geirinhas et al. 2011).

So, wherever underground chalcopyrite's veins become lixiviated and minerals are brought to the surface, there is the possibility of them being redeposited as gossam. This possibility requires a complete re-evaluation of possible copper sources for most of Iberia.

The Cabeço do Cucão site (CCPC) is located at the top of the southern slope of the Dão valley, occupying the two platforms and the surrounding area of a small granitic tor (Fig. 3). It is situated $650 \mathrm{~m}$ at the NW of the village of Pedra Cavaleira, parish of Silgueiros, municipality of Viseu (Senna-Martinez et al. 1993). One of the possible functionalities of this site is as a lookout or watchtower for the contemporary habitat of the Outeiro do Cabeço dos Castelos de Beijós (COCB), 


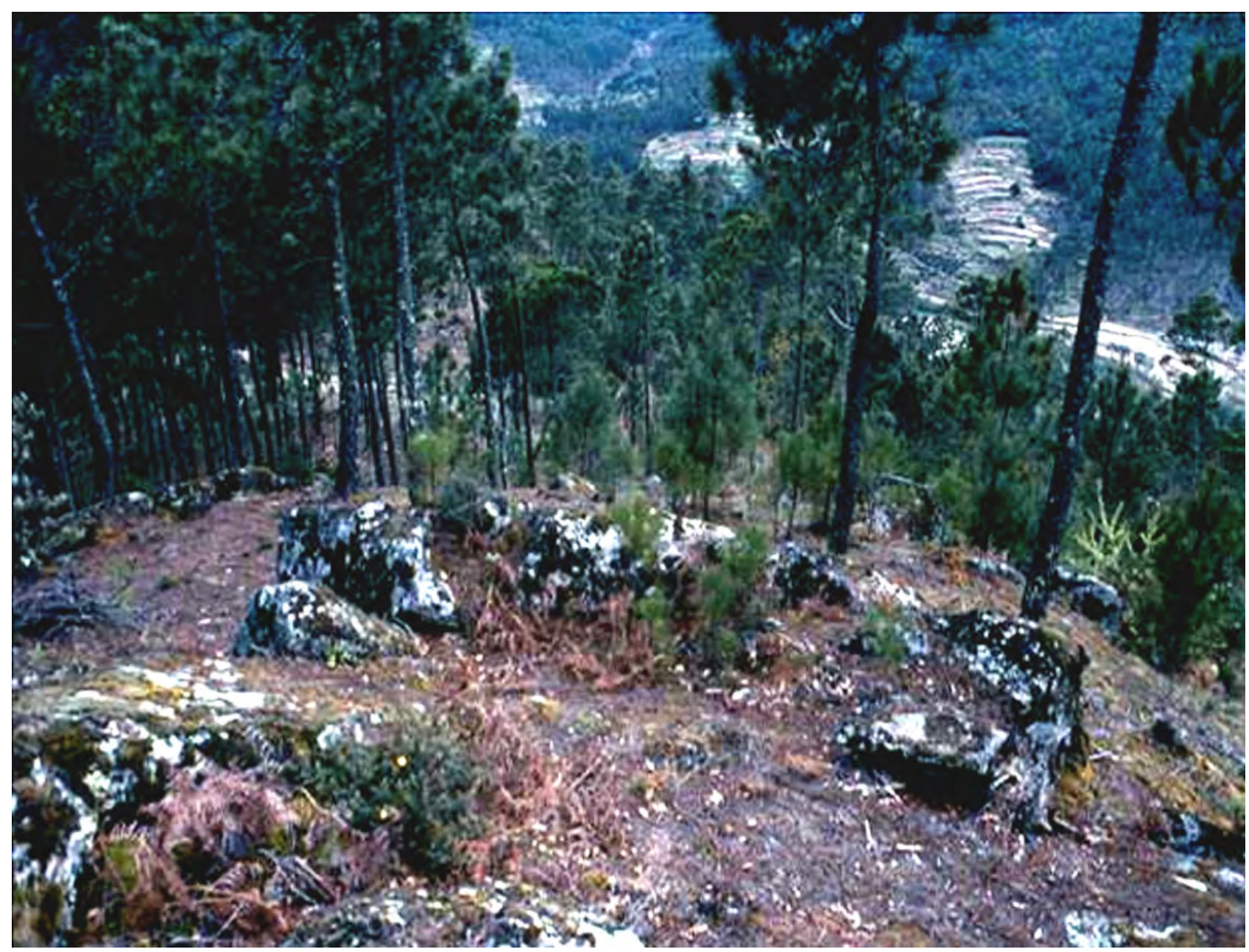

FIG. 3 Cabeço do Cucão da Pedra Cavaleira in 1985. View from the upper platform over the river Dão towards northwest.

with which it would have visual contact at a distance of about $4 \mathrm{~km}$ south. The site has a good domain of the surrounding landscape, especially along the Dão valley, both upstream and downstream. The moulds here under study were surface recoveries near the base of the tor, the last one after the 2017 forest fires in Central Portugal.

\section{ARTEFACT SAMPLE DATABASE AND TYPOLOGY}

The reference numbers, typology, provenance, material and main references for the artefacts studied in this paper are summarized in Table 1. These artefacts comprise: parts of two multiple parts moulds for unifacial palstaves, two halves of a multiple parts mould for bifacial palstaves, two fragments of a half of a multiple parts mould for lance-heads and chisels, an open-mould for chisels, four open moulds for awls, twelve fragments of lost-wax mould for lance-heads, and six fragments of lost-wax mould cores, in a total of 27 different artefacts or artefact-parts.

All the above mentioned typologies were already referenced before for the cultural group under discussion (Senna-Martinez et al. 2011). Nevertheless, whence quantified and taken together, they provide a very convincing picture of the technological capabilities of the LBA artisans that used them.

Metallic and stone moulds were already known for Western Iberia LBA (see for example Coffyn 1985) but, lost-wax mould fragments only impacted academic attention after the discovery of the ones found at the sites of Castro de Baiões (CSGB - Silva - Silva - Lopes 1984; Senna-Martinez - Pedro 2000a - Figs. 2-3) and Cabeço do Crastro de S. Romão (CSR - Gil et al. 1989), which was brought to general public knowledge during the Por Terras de Viriato exhibition of 2000/ 2001 at the Lisbon National Museum of Archaeology (Senna-Martinez - Pedro 2000). 


\begin{tabular}{|c|c|c|c|c|}
\hline REF. NUMBER & TYPOLOGY & PROVENANCE & MATERIAL & BIBLIOGRAPHY \\
\hline CCPC-M2 & $\begin{array}{l}\text { Half multiple parts } \\
\text { mould for unifacial } \\
\text { palstaves }\end{array}$ & $\begin{array}{l}\text { Cabeço do Cucão, Pedra } \\
\text { Cavaleira (Viseu) }\end{array}$ & Bronze & Unpublished \\
\hline CCPC-M1 & $\begin{array}{l}2 \text { fragments of a half } \\
\text { of a multiple parts } \\
\text { mould for lance-heads and } \\
\text { chisels }\end{array}$ & $\begin{array}{l}\text { Cabeço do Cucão, Pedra } \\
\text { Cavaleira (Viseu) }\end{array}$ & Sandstone & $\begin{array}{l}\text { Senna-Martinez (2011: Fig. 3); } \\
\text { Senna-Martinez, et al. (2011: Fig. 5) }\end{array}$ \\
\hline $\begin{array}{l}\text { CSGB ME- } \\
116 / 117\end{array}$ & $\begin{array}{l}\text { Multiple parts mould } \\
\text { for unifacial palstaves }\end{array}$ & $\begin{array}{l}\text { Castro da Senhora da Guia, } \\
\text { Baiões (São Pedro do Sul) }\end{array}$ & Bronze & $\begin{array}{l}\text { Senna-Martinez and Pedro (2000); } \\
\text { Senna-Martinez and Pedro, Eds. } \\
\text { (2000) }\end{array}$ \\
\hline CSGB MF1 & $\begin{array}{l}\text { Fragment of lost-wax } \\
\text { mould for lance-heads }\end{array}$ & $\begin{array}{l}\text { Castro da Senhora da Guia, } \\
\text { Baiões (São Pedro do Sul) }\end{array}$ & Fired clay & $\begin{array}{l}\text { Senna-Martinez and Pedro (2000); } \\
\text { Senna-Martinez and Pedro, Eds. } \\
\text { (2000) }\end{array}$ \\
\hline CSGB MF4 & $\begin{array}{l}\text { Fragment of lost-wax } \\
\text { mould for lance-heads }\end{array}$ & $\begin{array}{l}\text { Castro da Senhora da Guia, } \\
\text { Baiões (São Pedro do Sul) }\end{array}$ & Fired clay & $\begin{array}{l}\text { Senna-Martinez and Pedro (2000); } \\
\text { Senna-Martinez and Pedro, Eds. } \\
\text { (2000) }\end{array}$ \\
\hline CSGB MF6 & $\begin{array}{l}\text { Fragment of lost-wax } \\
\text { mould for lance-heads }\end{array}$ & $\begin{array}{l}\text { Castro da Senhora da Guia, } \\
\text { Baiões (São Pedro do Sul) }\end{array}$ & Fired clay & $\begin{array}{l}\text { Senna-Martinez and Pedro (2000); } \\
\text { Senna-Martinez and Pedro, Eds. } \\
\text { (2000) }\end{array}$ \\
\hline CSGB MF7 & $\begin{array}{l}\text { Fragment of lost-wax } \\
\text { mould for lance-heads }\end{array}$ & $\begin{array}{l}\text { Castro da Senhora da Guia, } \\
\text { Baiões (São Pedro do Sul) }\end{array}$ & Fired clay & $\begin{array}{l}\text { Senna-Martinez and Pedro (2000); } \\
\text { Senna-Martinez and Pedro, Eds. } \\
\text { (2000) }\end{array}$ \\
\hline CSGB MF9 & $\begin{array}{l}\text { Fragment of lost-wax } \\
\text { mould for lance-heads }\end{array}$ & $\begin{array}{l}\text { Castro da Senhora da Guia, } \\
\text { Baiões (São Pedro do Sul) }\end{array}$ & Fired clay & $\begin{array}{l}\text { Senna-Martinez and Pedro (2000); } \\
\text { Senna-Martinez and Pedro, Eds. } \\
\text { (2000) }\end{array}$ \\
\hline CSGB MF30 & $\begin{array}{l}\text { Fragment of lost-wax } \\
\text { mould for lance-heads }\end{array}$ & $\begin{array}{l}\text { Castro da Senhora da Guia, } \\
\text { Baiões (São Pedro do Sul) }\end{array}$ & Fired clay & $\begin{array}{l}\text { Senna-Martinez and Pedro (2000); } \\
\text { Senna-Martinez and Pedro, Eds. } \\
\text { (2000) }\end{array}$ \\
\hline CSGB MF31 & $\begin{array}{l}\text { Fragment of lost-wax } \\
\text { mould for lance-heads }\end{array}$ & $\begin{array}{l}\text { Castro da Senhora da Guia, } \\
\text { Baiões (São Pedro do Sul) }\end{array}$ & Fired clay & $\begin{array}{l}\text { Senna-Martinez and Pedro (2000); } \\
\text { Senna-Martinez and Pedro, Eds. } \\
\text { (2000) }\end{array}$ \\
\hline CSGB MF32 & $\begin{array}{l}\text { Fragment of lost-wax } \\
\text { mould for lance-heads }\end{array}$ & $\begin{array}{l}\text { Castro da Senhora da Guia, } \\
\text { Baiões (São Pedro do Sul) }\end{array}$ & Fired clay & $\begin{array}{l}\text { Senna-Martinez and Pedro (2000); } \\
\text { Senna-Martinez and Pedro, Eds. } \\
\text { (2000) }\end{array}$ \\
\hline CSGB MF33 & $\begin{array}{l}\text { Fragment of lost-wax } \\
\text { mould for lance-heads }\end{array}$ & $\begin{array}{l}\text { Castro da Senhora da Guia, } \\
\text { Baiões (São Pedro do Sul) }\end{array}$ & Fired clay & $\begin{array}{l}\text { Senna-Martinez and Pedro (2000); } \\
\text { Senna-Martinez and Pedro, Eds. } \\
\text { (2000) }\end{array}$ \\
\hline CSGB MF21 & $\begin{array}{l}\text { Fragment of lost-wax } \\
\text { mould core }\end{array}$ & $\begin{array}{l}\text { Castro da Senhora da Guia, } \\
\text { Baiões (São Pedro do Sul) }\end{array}$ & Fired clay & $\begin{array}{l}\text { Senna-Martinez and Pedro (2000); } \\
\text { Senna-Martinez and Pedro, Eds. } \\
\text { (2000) }\end{array}$ \\
\hline
\end{tabular}




\begin{tabular}{|c|c|c|c|c|}
\hline REF. NUMBER & TYPOLOGY & PROVENANCE & MATERIAL & BIBLIOGRAPHY \\
\hline CSGB MF23 & $\begin{array}{l}\text { Fragment of lost-wax } \\
\text { mould core }\end{array}$ & $\begin{array}{l}\text { Castro da Senhora da Guia, } \\
\text { Baiões (São Pedro do Sul) }\end{array}$ & Fired clay & $\begin{array}{l}\text { Senna-Martinez and Pedro (2000); } \\
\text { Senna-Martinez and Pedro, Eds. } \\
\text { (2000) }\end{array}$ \\
\hline CSGB MF24 & $\begin{array}{l}\text { Fragment of lost-wax } \\
\text { mould core }\end{array}$ & $\begin{array}{l}\text { Castro da Senhora da Guia, } \\
\text { Baiões (São Pedro do Sul) }\end{array}$ & Fired clay & $\begin{array}{l}\text { Senna-Martinez and Pedro (2000); } \\
\text { Senna-Martinez and Pedro, Eds. } \\
\text { (2000) }\end{array}$ \\
\hline CSGB MF34 & $\begin{array}{l}\text { Fragment of lost-wax } \\
\text { mould core }\end{array}$ & $\begin{array}{l}\text { Castro da Senhora da Guia, } \\
\text { Baiões (São Pedro do Sul) }\end{array}$ & Fired clay & $\begin{array}{l}\text { Senna-Martinez and Pedro (2000); } \\
\text { Senna-Martinez and Pedro, Eds. } \\
\text { (2000) }\end{array}$ \\
\hline CSGB MF35 & $\begin{array}{l}\text { Fragment of lost-wax } \\
\text { mould core }\end{array}$ & $\begin{array}{l}\text { Castro da Senhora da Guia, } \\
\text { Baiões (São Pedro do Sul) }\end{array}$ & Fired clay & $\begin{array}{l}\text { Senna-Martinez and Pedro (2000); } \\
\text { Senna-Martinez and Pedro, Eds. } \\
(2000)\end{array}$ \\
\hline CSGB MF36 & $\begin{array}{l}\text { Fragment of lost-wax } \\
\text { mould core }\end{array}$ & $\begin{array}{l}\text { Castro da Senhora da Guia, } \\
\text { Baiões (São Pedro do Sul) }\end{array}$ & Fired clay & $\begin{array}{l}\text { Senna-Martinez and Pedro (2000); } \\
\text { Senna-Martinez and Pedro, Eds. } \\
\text { (2000) }\end{array}$ \\
\hline CSGB MF-3 & $\begin{array}{l}\text { Fragment of open-mould } \\
\text { for awls }\end{array}$ & $\begin{array}{l}\text { Castro da Senhora da Guia, } \\
\text { Baiões (São Pedro do Sul) }\end{array}$ & Granite & $\begin{array}{l}\text { Senna-Martinez and Pedro (2000); } \\
\text { Senna-Martinez and Pedro, Eds. } \\
\text { (2000) }\end{array}$ \\
\hline MGV 2891 & $\begin{array}{l}\text { Fragment of open-mould } \\
\text { for awls }\end{array}$ & Castro de Santa Luzia & Granite & $\begin{array}{l}\text { Senna-Martinez and Pedro (2000); } \\
\text { Senna-Martinez and Pedro, Eds. } \\
\text { (2000) }\end{array}$ \\
\hline MGV 2890 & Open-mould for chisels & Castro de Santa Luzia & Granite & $\begin{array}{l}\text { Senna-Martinez and Pedro (2000); } \\
\text { Senna-Martinez and Pedro, Eds. } \\
(2000)\end{array}$ \\
\hline No number & Mould for bifacial palstaves & Vila Boa, Castro Daire & Bronze & Teixeira (1939-42) \\
\hline CSR 5098 & $\begin{array}{l}\text { Fragment of lost-wax } \\
\text { mould for lance-heads }\end{array}$ & $\begin{array}{l}\text { Cabeço do Crasto } \\
\text { de São Romão }\end{array}$ & Fired clay & $\begin{array}{l}\text { Gil, et al. (1989); Senna-Martinez } \\
\text { and Pedro (2000); Senna-Martinez } \\
\text { and Pedro, Eds. (2000) }\end{array}$ \\
\hline CSR 5000 & $\begin{array}{l}\text { Fragment of lost-wax } \\
\text { mould for lance-heads }\end{array}$ & $\begin{array}{l}\text { Cabeço do Crasto } \\
\text { de São Romão }\end{array}$ & Fired clay & $\begin{array}{l}\text { Gil, et al. (1989); Senna-Martinez } \\
\text { and Pedro (2000); Senna-Martinez } \\
\text { and Pedro, Eds. (2000) }\end{array}$ \\
\hline CSR 919 & $\begin{array}{l}\text { Fragment of lost-wax } \\
\text { mould for lance-heads }\end{array}$ & $\begin{array}{l}\text { Cabeço do Crasto } \\
\text { de São Romão }\end{array}$ & Fired clay & $\begin{array}{l}\text { Gil, et al. (1989); Senna-Martinez } \\
\text { and Pedro (2000); Senna-Martinez } \\
\text { and Pedro, Eds. (2000) }\end{array}$ \\
\hline CSR 2475 & $\begin{array}{l}\text { Fragment of open-mould } \\
\text { for awls }\end{array}$ & $\begin{array}{l}\text { Cabeço do Crasto } \\
\text { de São Romão }\end{array}$ & Granite & $\begin{array}{l}\text { Gil, et al. (1989) ; Senna-Martinez } \\
\text { and Pedro (2000); Senna-Martinez } \\
\text { and Pedro, Eds. (2000) }\end{array}$ \\
\hline CSR 7101 & $\begin{array}{l}\text { Fragment of open-mould } \\
\text { for awls }\end{array}$ & $\begin{array}{l}\text { Cabeço do Crasto } \\
\text { de São Romão }\end{array}$ & Granite & $\begin{array}{l}\text { Gil, et al. (1989); Senna-Martinez } \\
\text { and Pedro (2000); Senna-Martinez } \\
\text { and Pedro, Eds. (2000) }\end{array}$ \\
\hline
\end{tabular}




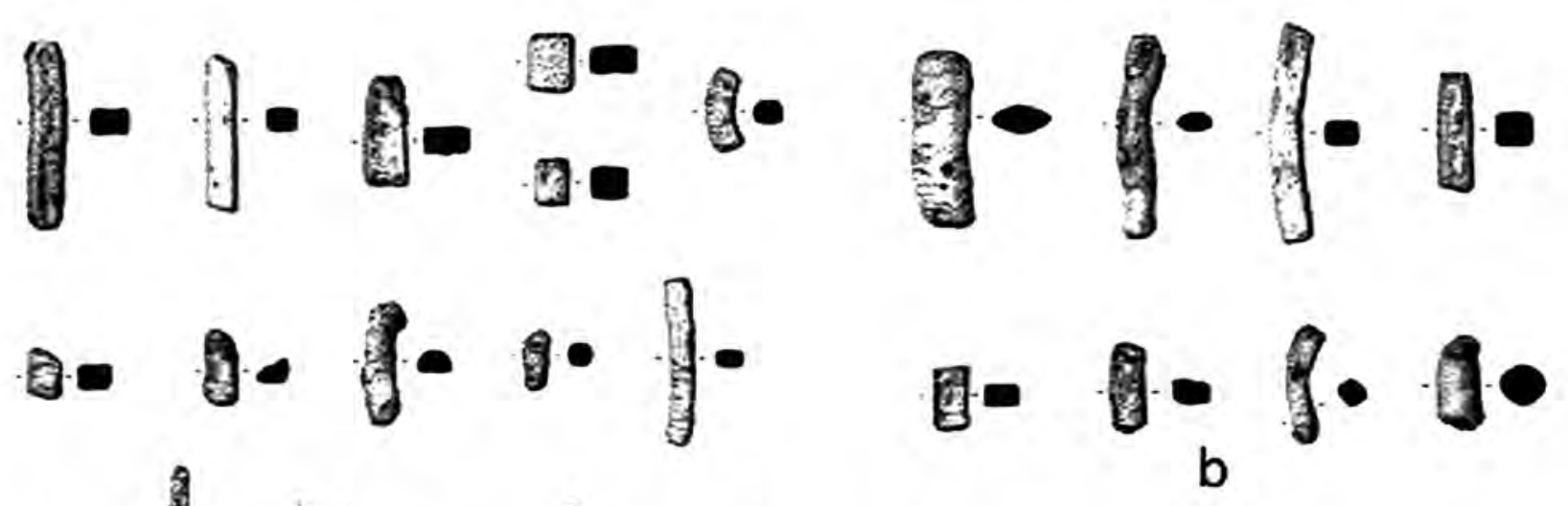

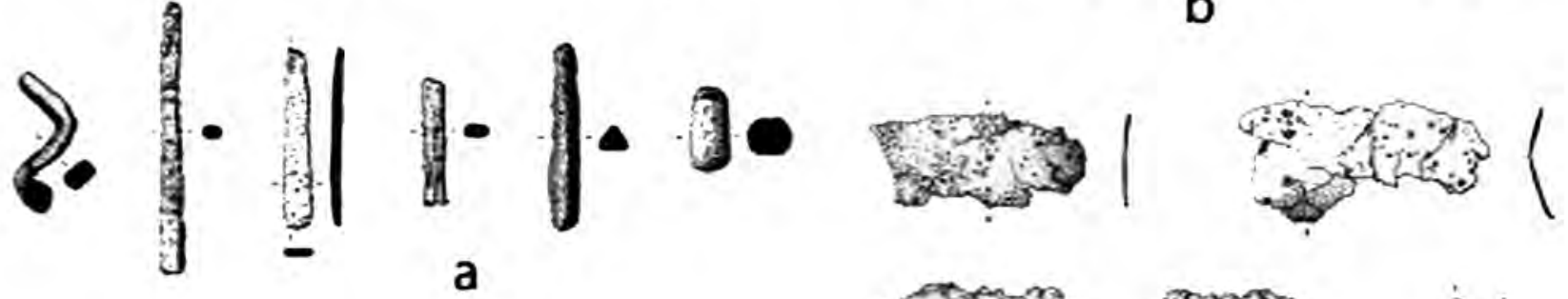
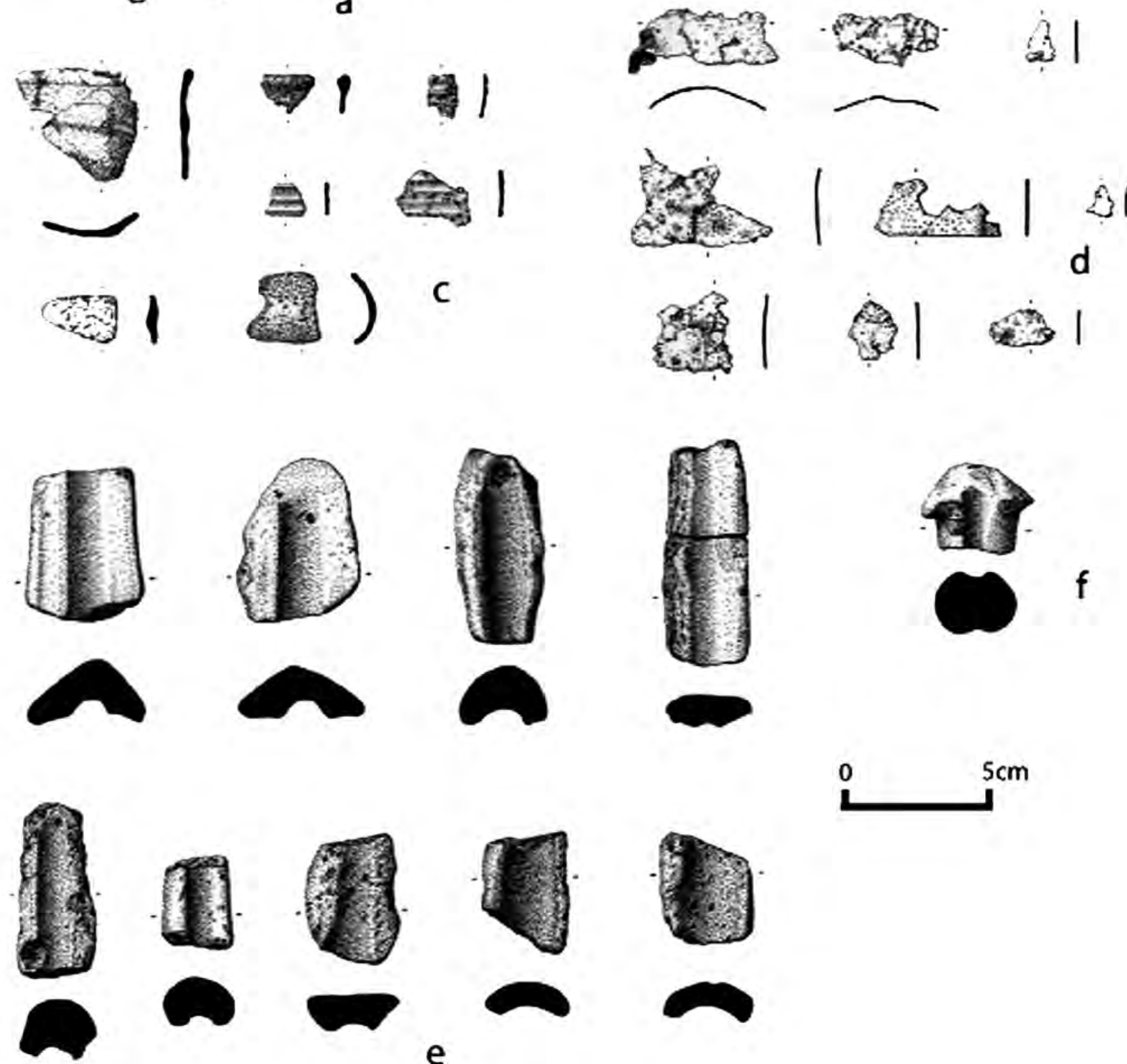

e

FIG. 4 Castro da Senhora da Guia de Baiões, metallurgical remains: a, b - bronze bar fragments; c - bronze sheet fragments; $\mathrm{d}$ - bronze riveted sheet fragments; e - cire perdue clay mould fragments; $f$ - clay core fragment. 
The main recovery problem with these lost-wax mould fragments is that, to a more careless and incautious excavator, they are easily mistaken for a normal pottery sherd or even a daub fragment. We find it strange that there is no notice of other cases of finding lost-wax mould fragments from other extensively excavated LBA settlements from Western Iberia (namely from the Portuguese Beiras), with well documented metallurgical practices (Vilaça 1995; 1997; Canha 2002; Vilaça - Montero Ruiz 2004).

So, up to now, the lost-wax mould fragments collections from CSGB and CSR (total 18) are the only ones we can study. The typology of the produced artefacts is reduced to only lance-heads ( 9 from CSGB - Fig. 4 and 3 from (SR) and undifferentiated core parts (6 from CSGB - Fig. 5) used to produce the hollow shaft either of lances or other unidentifiable types.

Besides being the more numerous, lost-wax ones are the only moulds made of fired-clay in the Baiões / Santa Luzia LBA cultural group.

Stone moulds fragments, made of fine grained granites, show a larger variety of typologies but are less numerous with only six exemplars: (1) 4 are fragments of open-moulds for awls - 2 from CSR, 1 from CSGB and another from CSL; (2) from CSL comes an open-mould for chisels together with a bronze chisel probably cast in it; (3) the last stone exemplar is constituted by two connecting fragments of a half of a multiple parts mould (Fig. 6) for lance-heads and chisels (Senna-Martinez Pedro 2000a: 65, Fig. 3; Senna-Martinez 2011:289, Fig. 3) from the lookout site of Cabeço do Cucão da Pedra Cavaleira (CCPC - Senna-Martinez et al. 1993).

The final group of moulds that we address here are the metallic ones, in the instance all made of binary bronze (see ahead): (1) the first exemplar to be known (Fig. 7) and published is composed by the two halves of a multiple parts mould for bifacial palstaves from Vila Boa (Castro d'Aire - Teixeira 1939-1942); (2) from another location come the also well-known two halves from a multiple parts mould (Fig. 8) for unifacial palstaves from CSGB (S. Pedro do Sul - Silva - Silva - Lopes 1984; Armbruster 2000) that was found, together with a cast-in palstave, in what seems to be a foundry atelier (Senna-Martinez - Pedro 2000a); (3) finally we study here a previously unknown exemplar of a half of a multiple parts mould for unifacial palstaves (Figs. 9-10), also found at the lookout site of CCPC.

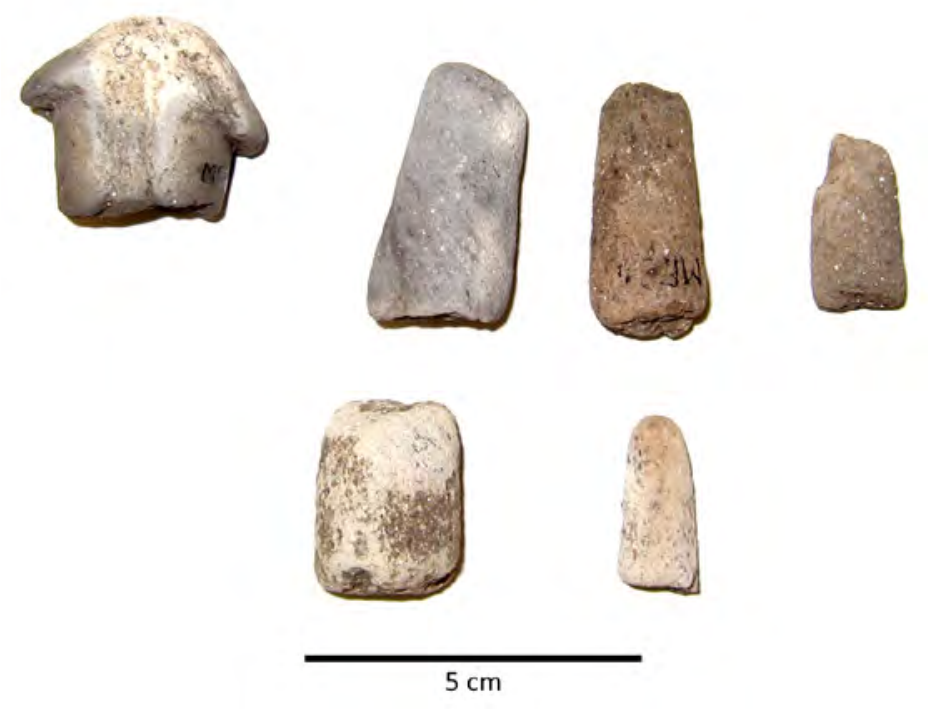

FIG. 5 Castro da Senhora da Guia de Baiões, core fragments.
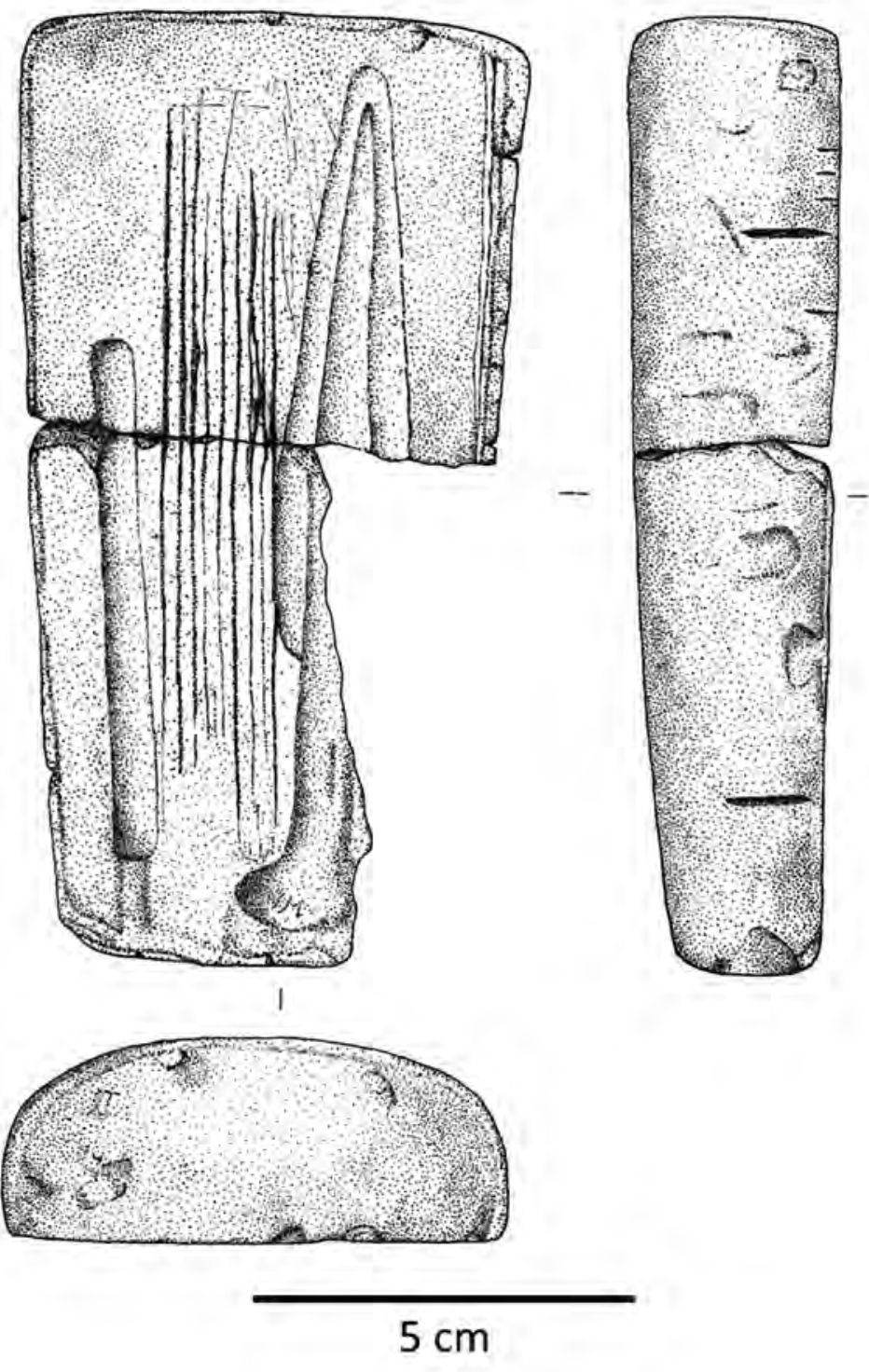

FIG. 6 Cabeço do Cucão da Pedra Cavaleira, two fragments of a half of a multiple parts mould for lance-heads and chisels. 


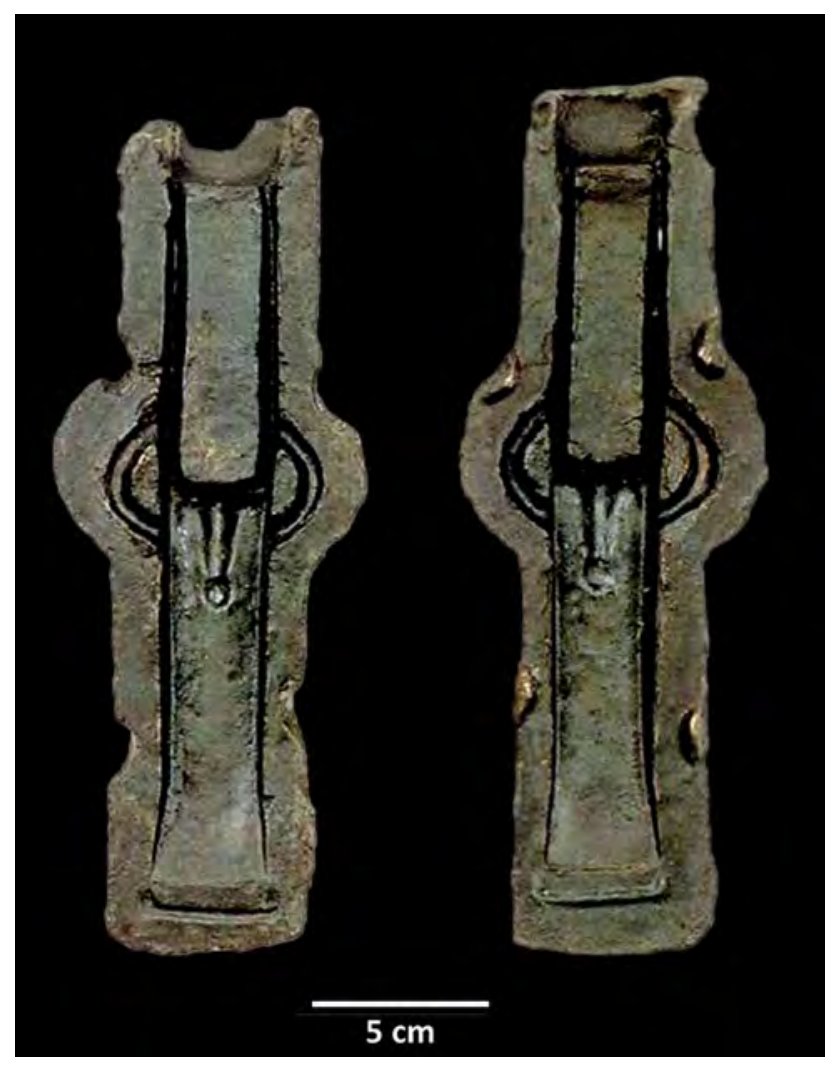

FIG. 7 Castro d'Aire, Vila Boa, two halves of a multiple parts mould for bifacial palstaves.

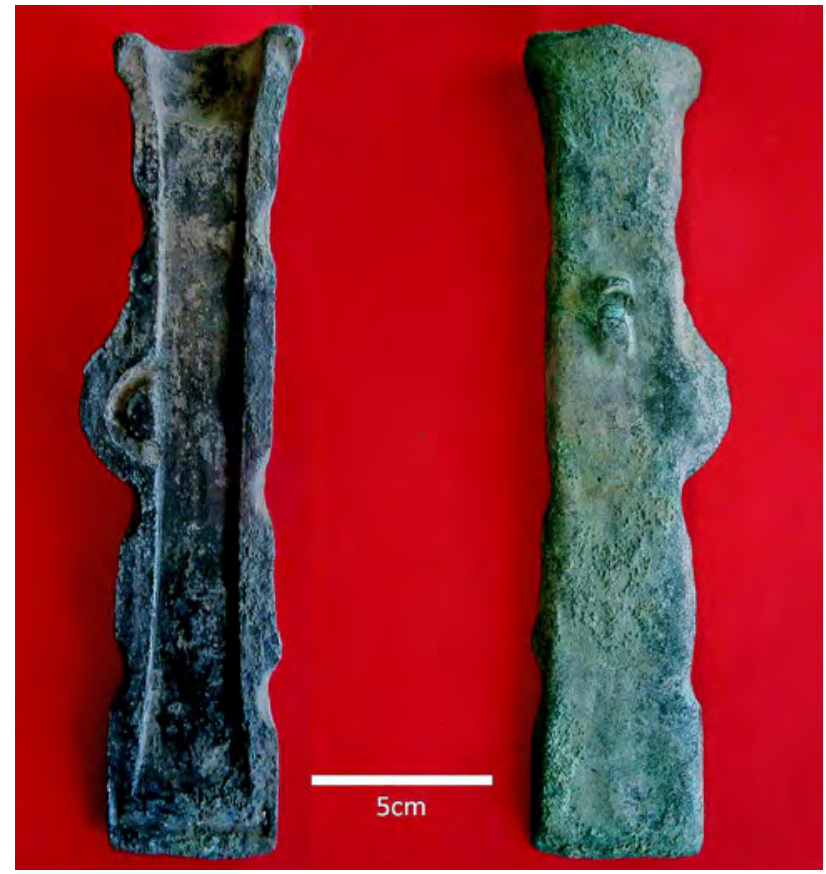

FIG. 9 Cabeço do Cucão da Pedra Cavaleira, half of a multiple parts mould for unifacial palstaves.

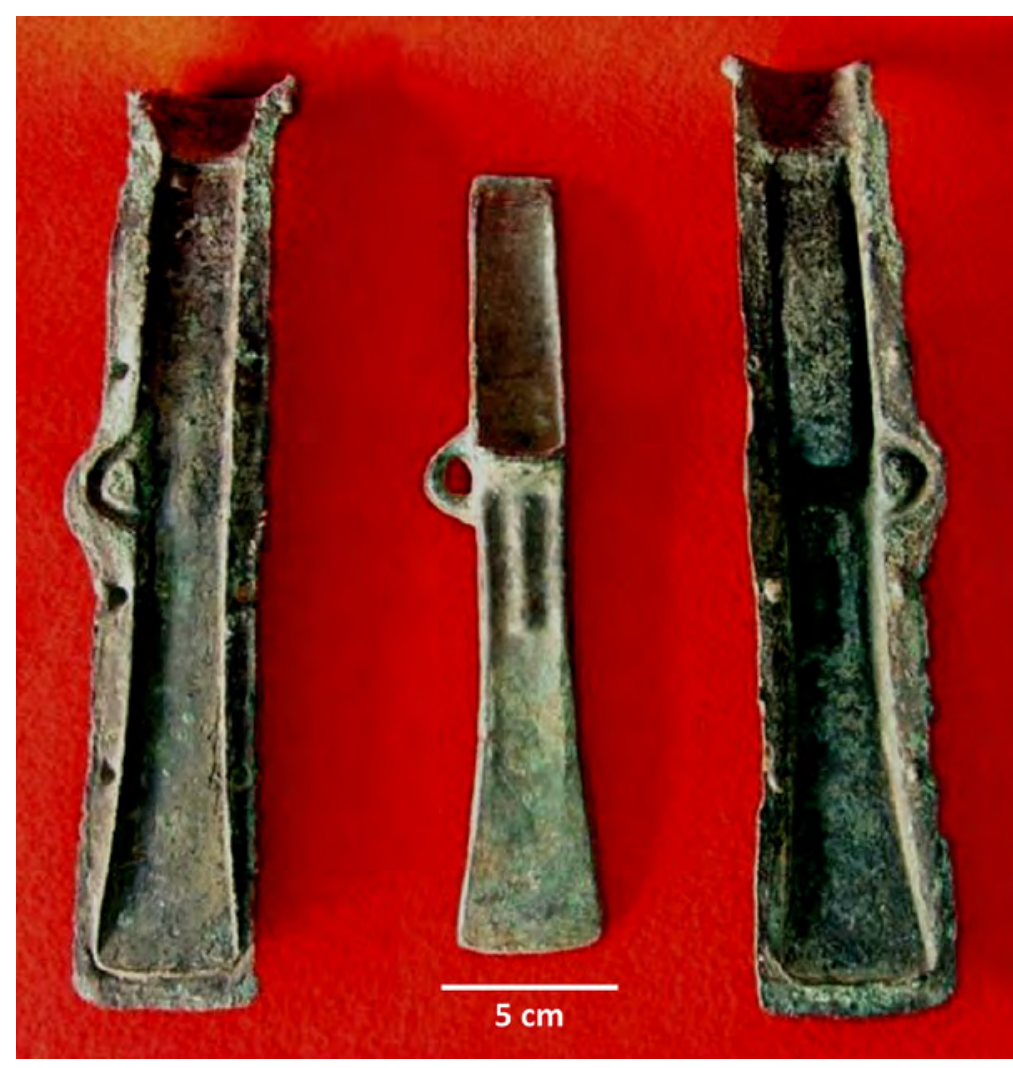

FIG. 8 Castro da Senhora da Guia de Baiões, two halves from a multiple parts mould for unifacial palstaves and a cast-in palstave.

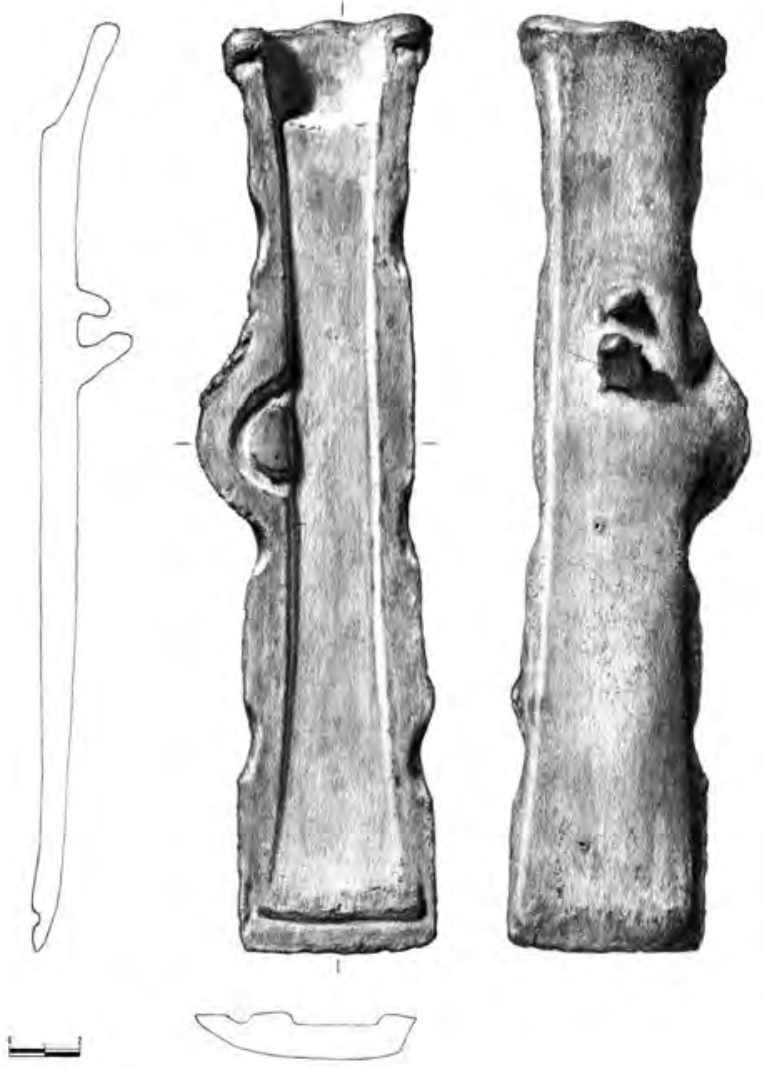

FIG. 10 Cabeço do Cucão da Pedra Cavaleira, drawing by Artur Ramos of a half of a multiple parts mould for unifacial palstaves. 
The dimensions of CCPC mould half are as follows:

\begin{tabular}{lc}
\hline - Length & $27.1 \mathrm{~cm}$ \\
\hline - Width of distal end & $5.4 \mathrm{~cm}$ \\
\hline - Width of proximal end & $6.2 \mathrm{~cm}$ \\
\hline - Maximum thickness & $1.1 \mathrm{~cm}$ \\
\hline - Minimum thickness & $0.7 \mathrm{~cm}$ \\
\hline
\end{tabular}

For the cast-in palstave the dimensions would be approximately:

\begin{tabular}{lr}
\hline - Length & $23.3 \mathrm{~cm}$ \\
\hline - Width of distal end & $4.2 \mathrm{~cm}$ \\
\hline - Width of proximal end & $2.7 \mathrm{~cm}$ \\
\hline - Thickness of the loop & $0.55 \mathrm{~cm}$ \\
\hline - Width of the loop & $1.5 \mathrm{~cm}$ \\
\hline
\end{tabular}

\section{ARCHAEOMETRIC CHARACTERIZATION OF THE MOULD FROM CABEÇO DO CUCÃO DA PEDRA CAVALEIRA}

The metallic mould of CCPC was first subjected to a preparation procedure consisting on the removal of the superficial corrosion layer in a very small area (3-5 mm diameter), to expose a clean metal surface for microanalysis. Details on preparation procedure and following micro-EDXRF analysis to establish the alloy composition were previously published (Valério et al. 2015a). Thereafter, the elemental characterization by micro-EDXRF determined that the mould from CCPC is composed by a binary bronze alloy (Table 2 ).

TABLE 2 CHEMICAL COMPOSITION OF THE PALSTAVES MOULD FROM CCPC

\begin{tabular}{cccc} 
& $\mathrm{Cu}$ & $\mathrm{Sn}$ & As \\
\hline $\mathrm{CCPC}-\mathrm{M} 2$ & $86.5 \pm 0.9 \%$ & $13.3 \pm 0.9 \%$ & $0.13 \pm 0.01 \%$ \\
\hline
\end{tabular}

The two halves (CSGB ME-116/117) of the mould for unifacial palstaves from CSGB were analysed many years ago following a non-invasive methodology that hinders the determination of the alloy composition, nevertheless the elemental characterization made also identified a binary bronze alloy (Valério et al. 2006). In fact, the LBA metallurgy of the Baiões / Santa Luzia cultural group of Central Portugal seems to be dominated by the production of binary bronzes with suitable tin contents ${ }^{2}$, i.e. $13 \pm 3 \%$ Sn (Senna-Martinez et al. 2011). The major sources of tin with prehistoric exploration in this region would have provided a steady supply of cassiterite to local settlements, while distant territories such as southern Portugal would have had more difficulty in the supply of such raw material, thus showing a bronze metallurgy with somewhat lower amount of tin, i.e. $10 \pm 2 \%$ Sn (Valério et al. 2018).
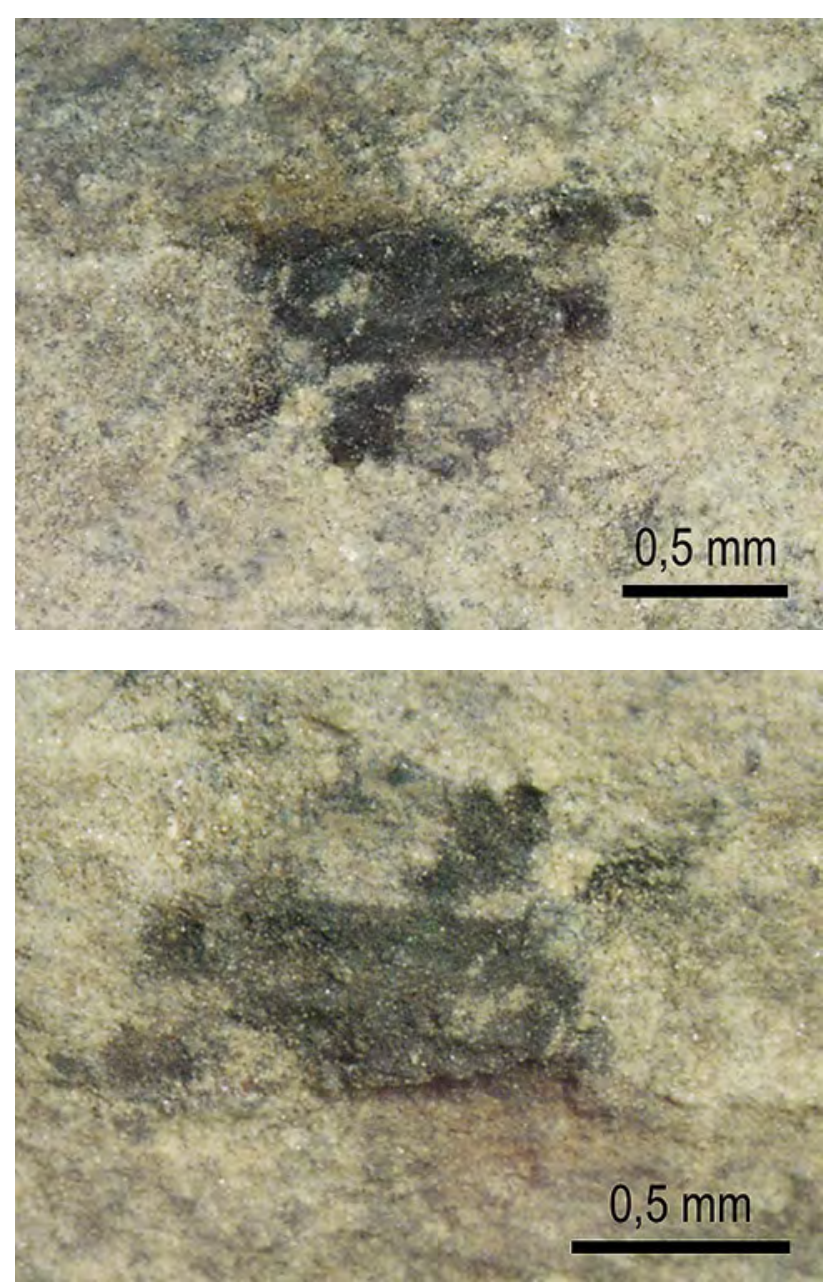

FIG. 11 Blackish residue on the inner face of a half of a multiple parts mould for unifacial palstaves from Cabeço do Cucão da Pedra Cavaleira.

\footnotetext{
"...The 'control' over Sn content in the artefacts, could possibly be achieved by the awareness of the colour (and hardness?) of the metals. The Sn content range of $\sim 10-15 \%$ (most of the artefacts) produces a metal with a yellowish 'gold like' colour that was probably appreciated, besides its good thermomechanical properties..." and "...The relatively high Sn content among the studied items ( 13 $\pm 3 \% \mathrm{Sn})$ and absence of low tin bronzes may suggest that the exploitation of local tin ores was a reality (although in a relative low scale), resulting in an constant tin supply, and thus enforcing the role of metallurgy and associated activities in the site / region..." (Figueiredo et al. 2010b:1633).
} 


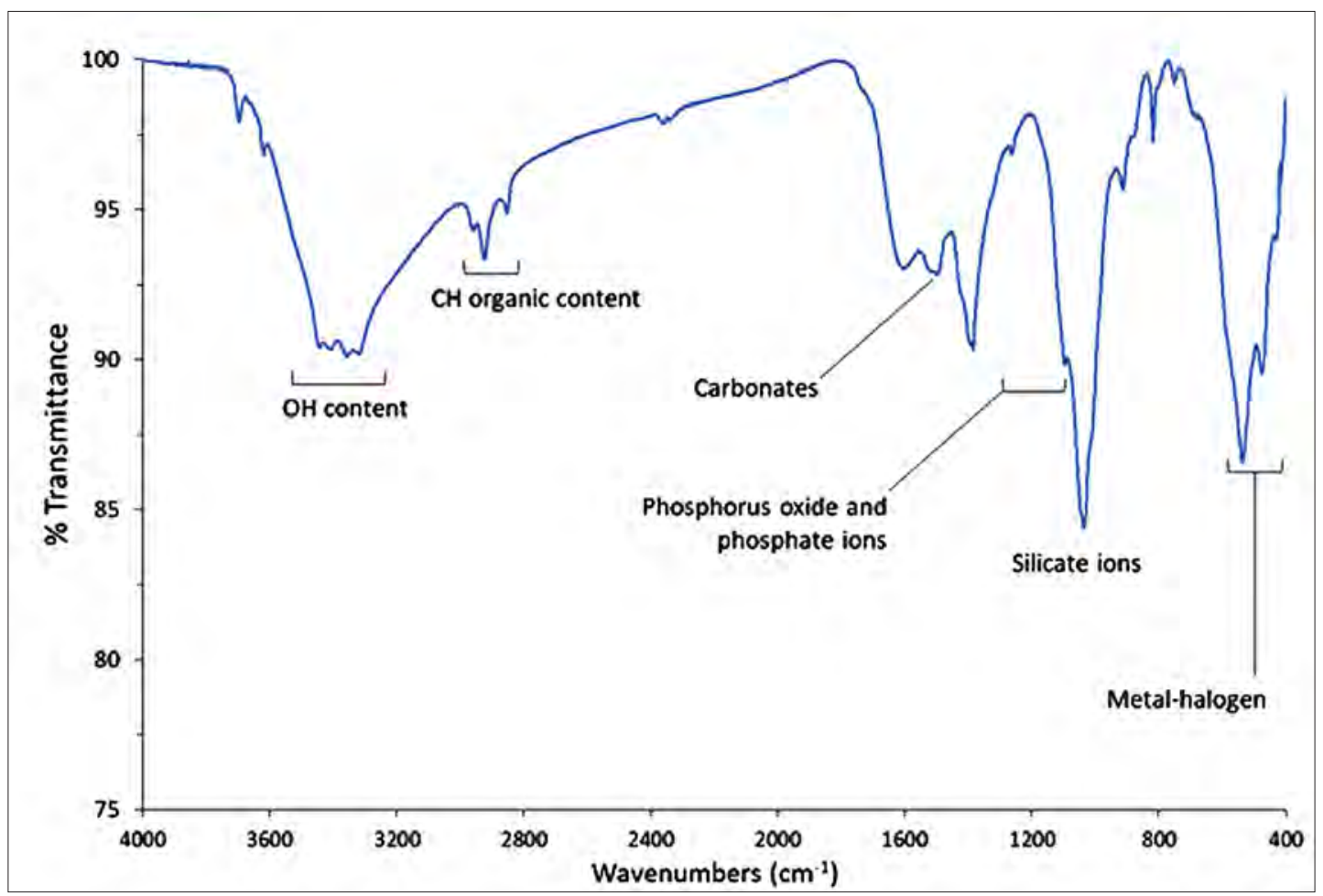

FIG. 12 Obtained FTIR spectrum recorded from a KBr disk on a Thermo Scientific (Nicolet) i50 spectrometer from the blackish residue on the inner face of a half of a multiple parts mould for unifacial palstaves from Cabeço do Cucão da Pedra Cavaleira.

The existence on the inner face of the mould of a blackish residue (Fig. 11), clearly distinguishable from the soil adhering to the artefact, suggested the possible use of a coating material applied to prevent the axe from adhering to the inner face of the mould during the casting operation.

The blackish residue was analysed by Fourier Transform Infrared (FTIR) spectroscopy. FTIR spectrum was recorded from a $\mathrm{KBr}$ disk on a Thermo Scientific (Nicolet) i50 spectrometer. The spectrum was recorded at ambient temperature between 400 and $4000 \mathrm{~cm}^{-1}$, at a resolution of $4 \mathrm{~cm}^{-1}$, by scanning 64 times. Before analysis the $\mathrm{KBr}$ disk containing the sample was kept under vacuum (10-2 mbar) for $48 \mathrm{~h}$ at $45^{\circ} \mathrm{C}$.

The comparison of the obtained spectrum (Fig. 12) with reference spectra data from HR Inorganics Library (Thermo Scientific $^{\text {TM }}$ Nicolet $^{\text {TM }}$ FTIR Spectral Library 2012) and Mineralogy Database (Mineralogy Database 2020), suggested that the blackish residue is composed mainly by clay minerals griphite and illite, evidencing also some traces of bentonite. Griphite is an accessory mineral in complex granites pegmatites consisting of basic phosphate of sodium, calcium, iron, aluminium and manganese, $\left.(\mathrm{Na}, \mathrm{Al}, \mathrm{Ca}, \mathrm{Fe})_{6} \mathrm{Mn}_{4}\left(\mathrm{PO}_{4}\right)_{5}(\mathrm{OH})_{4}\right)$. Illite is a group of non-expanding micalike clays, usually interlayered muscovite and montmorillonite minerals $\left(\mathrm{K}_{1} \mathrm{H}_{3} \mathrm{O}\right)$ $(\mathrm{Al}, \mathrm{Mg}, \mathrm{Fe})_{2}(\mathrm{Si}, \mathrm{Al})_{4} \mathrm{O}_{10}\left[(\mathrm{OH})_{2,}\left(\mathrm{H}_{2} \mathrm{O}\right)\right]$. Bentonite is a mixture of very fine grain clays, composed mainly by montmorillonite (60 to $80 \%$ ) but may also contain quartz, feldspars, pyrite or calcite (Mineralogy Database 2020). It was also detected the presence of some carbonates (vibrations in $1492 \mathrm{~cm}^{-1}$ region), maybe originated in carbonation processes during the long burial period of the mould, as well as the presence of organic functional groups $\left(\approx 2970-2360 \mathrm{~cm}^{-1}\right)$ which can be associated to environmental contaminations.

The main characteristic absorption bands observed in the blackish acquired spectra were assigned as follows (Silverstein - Bassier - Morril 1983; Coates 2006; IRUG 2020) (Table 3).

The use of clay or charcoal was suggested in a study of two LBA bronze moulds for casting palstaves from La Macolla, Salamanca (García-Vuelta et al. 2014), while the use of clay was documented among the LBA archaeological record of the British Isles (Webley - Adams 2016). Therefore, the use of clay should constitute an alternative technique to the already known bone black coating method identified in a LBA stone 
mould for flat axes from southern Portugal (Soares et al. 2009) as well as in a Galician exemplar (Figueiredo et al. 2017). A hypothesis (Baron - Miazga - Nowak 2014: 325) that a beeswax residue from a polish mould could have been used as a layer to prevent welding is improbable "...as the wax would tend to cause casting failures..." (Webley - Adams 2016). A better explanation is a dual use of the mould "...both to have cast metal (low tin content) and wax (beeswax remains), which makes it a good example of a multi-purpose tool used in various conditions..." (Baron - Miazga Nowak 2014: 336). The cast wax exemplars could then be used to produce clay cire perdue moulds.

\section{TABLE 3}

\begin{tabular}{|c|c|}
\hline ABSORPTION BAND & SIGNIFICANCE \\
\hline$\approx 3400 \mathrm{~cm}^{-1}$ & $\begin{array}{l}\mathrm{H}_{2} \mathrm{O} \text { content present in } \\
\text { minerals composition, either } \\
\text { in the form of } \mathrm{OH} \text { or as } \\
\text { hydration molecules }\end{array}$ \\
\hline$\approx 2970-2860 \mathrm{~cm}^{-1}$ & $\begin{array}{l}\text { Methyl }(\mathrm{C}-\mathrm{H}) \text { and metoxy } \\
\left(\mathrm{O}-\mathrm{CH}_{3}\right) \text { from organic content }\end{array}$ \\
\hline$\approx 2360 \mathrm{~cm}^{-1}$ & $\begin{array}{l}\text { Thiol compounds (R-SH) } \\
\text { and/or nitrogen compounds } \\
\text { (R-N) from organic content }\end{array}$ \\
\hline$\approx 1492 \mathrm{~cm}^{-1}$ & $\begin{array}{l}\text { Carbonate }\left(\mathrm{CO}_{3}{ }^{2-}\right) \text { groups } \\
\text { probably originated in soil } \\
\text { carbonations }\end{array}$ \\
\hline$\approx 1262-1096 \mathrm{~cm}^{-1}$ & $\begin{array}{l}\text { Phosphate }\left(\mathrm{PO}_{4}^{3-}\right) \text { group } \\
\text { vibrations from griphite }\end{array}$ \\
\hline$\approx 1036 \mathrm{~cm}^{-1}$ & $\begin{array}{l}\text { Silicate ions }\left(\mathrm{SiO}_{4}{ }^{2-}\right) \text { from } \\
\text { montmorillonite }\end{array}$ \\
\hline$\approx 912 \mathrm{~cm}^{-1}$ & $\begin{array}{l}\text { Permanganate ion }\left(\mathrm{MnO}_{4}^{-}\right) \\
\text {from griphite }\end{array}$ \\
\hline$\approx 900-700 \mathrm{~cm}^{-1}$ & $\begin{array}{l}\text { Calcium aluminate and } \\
\text { calcium sulfoaluminium from } \\
\text { griphite and } \mathrm{S}^{2-} \text { vibrations } \\
\text { probably from pyrite content }\end{array}$ \\
\hline$\approx 600-400 \mathrm{~cm}^{-1}$ & $\begin{array}{l}\text { Metal oxides and metal- } \\
\text {-halogen from clays mineral } \\
\text { content }\end{array}$ \\
\hline
\end{tabular}

As demonstrated by Elin Figueiredo and colleagues (Figueiredo et al. 2016) for the double moulds for Bujões MBA axes, casting of palstaves would probably be done similarly with the mould inclined at an angle of $\approx 25^{\circ}$ with the main axis of the axe (Figueiredo et al. 2016: 21 and Fig. 5), allowing for a smoother escape of gas/air.
We have no direct or experimental evidence for the production of these metallic moulds, especially the way the two halves would fit perfectly together, as demonstrated by the exemplars from Baiões and Castro d'Aire. One possibility would be by two cire perdue moulds built over a clay core palstave (Armbruster 2002-2003). The outer surface imperfections of the three exemplars here discussed could substantiate such a hypothesis. This question must, however, stay unresolved for the moment as we know no fragments of such moulds in our study area.

\section{FOUNDRY IN THE LATE BRONZE AGE BAIÕES / SANTA LUZIA CULTURAL GROUP, SOME FINAL REMARKS}

The first striking thing about Baiões/Santa Luzia metallurgy is that it probably constitutes a domestic artisanal and small scale endeavour widely dispersed in between all the habitat sites that were subjected to modern archaeological intervention (Senna-Martinez 1994; 2011). This situation - "...the very small-scale decentralized co-smelting and cementation of arsenical copper and tin bronze that is typical of Bronze Age Iberia..." - contrasts sharply with what is happening in the Eastern Mediterranean areas where the rule is "...the large-scale production of copper oxhide ingots from around $1500 \mathrm{BC}$ [as, for instance,] in Late Bronze Age Cyprus..." (Radivojević et al. 2019: 134).

Nevertheless the small scale (Rovira Llorens Montero Ruiz 2013: 232-234), the technical capabilities of the artisans are comparable to other areas of Atlantic Europe, mastering all the then known casting and forging techniques (Pare 2000; Senna-Martinez et al. 2011; Kienlin 2013; Valério et al. 2015a).

"...The development of local elites during the LBA has been linked to the role of metallurgy in producing status enhancing artifacts (expressed by the higher number of metallic artifact production, as well as their more complex shape and new techniques of production). So an easy access to the minerals must have been seen as an advantage, and can also be taken into account in the positioning of some emerging sites..." (Senna-Martinez et al. 2011: 412). The location of Castro de Santa Luzia (CSL) with its proximity to the Orgens mine surely substantiates this quoting (Vaz 2009). 
While the use of open moulds looks to be confined to very simple shapes - awls and chisels as in the cases reported in Table 1 - multiple parts moulds of stone or bronze were utilized for more complex artefacts, like palstaves and socketed spear-heads (Figs. 6-10). While the few fragments of clay cire perdue moulds document mostly a parallel production of socketed spear-heads, a more complex use is implicit in known overcasting processes like the one proved for the Figueiredo das Donas shield-nails (Figueiredo et al. 2011) or the one proposed for the Baiões flesh hook (Armbruster 2000; 2002-2003: 149). Cire perdue moulds could also be probably used to produce socketed sickles ${ }^{3}$.

One of us has been arguing as a model for the Central Portugal Late Bronze Age communities a very simple social and economic situation based on (Senna-Martinez - Pedro 2000a; Senna-Martinez - Luís 2016): (1) Self-consumption economies, based in the household domestic level, without the possibility of generating significant surpluses either in food or other products; (2) A non-mercantile circulation of goods, based on "down the line" mechanisms and solidarity networks between local elites; (3) Weakly structured "Polities" ${ }^{4}$ not going beyond the level of Earle's chieftainship concept (Earle 2002).

This model seems to be validated also by the available data on metallurgy as presented before (Senna-Martinez 2005; Senna-Martinez et al. 2011). The present discussion on foundry techniques and moulds does no change this overall picture.

The majority of the available data (Table 1) confirms the relative importance of the Baiões site (CSGB) as a focal point for bronze and gold artefacts production/concentration. This is the only site where all the known Baiões / Santa Luzia casting techniques are documented with 17 (63\%) out of the total 27 moulds or mould fragments known in the area. This fact matches the evidence on bronze items recovered at the site of CSGB (Senna-Martinez - Pedro 2000a: Table 2), when compared to the other excavated or surveyed sites of the Baiões / Santa Luzia world.

Recycling operations rather than faulty castings are probably responsible for the presence in CSGB

Local production is suggested by the exemplars of socketed sickle-blades from Baiões (CSGB) found "as cast" structures, still showing burrs (Armbruster 2000; 2002-2003).

$4 \quad$ In the sense proposed by Renfrew (Renfrew - Cherry 1986). and other sites of partially heat-deformed fragments of artefacts with recrystallized grain microstructures that point out to this explanation. Recycling was probably a frequent operation since more than 300 fragments of foundry leftovers and scrap, probably for remelting ${ }^{5}$, are present among the collection of CSGB (Senna-Martinez - Pedro 2000a).

CSGB is the site closest to the littoral of this cultural area, and we now know with enough dating evidence that the site began to be occupied during the last quarter of the second millennium BC and its abandonment probably occurred in the early seventh century BC (Senna-Martinez 2010; Table 1).

The great majority of bronze artefacts produced by Baiões / Santa Luzia metallurgists are of Atlantic typological affiliation but, an early presence - already during the last quarter of the second millennium BC - of some exemplars, and mostly models, of Mediterranean origin, shows probable pre-orientalizing connections (Senna-Martinez 2011). This presence is artefactually materialized by the recovering of the first fibulae, the first iron artefacts, and metal balance weights, as well as a special metallurgical technique for gold gilding that were found regionally.

Up to now, the Baiões/Santa Luzia culture group has the largest concentration ${ }^{6}$ of one of the oldest types of fibulae from Iberia: the so called "Roça do Casal do Meio" or "de enrolamento no arco" type (Gil et al. 1989). The period between $1200-800 \mathrm{cal}$ BC (based on ten C14 dates - Senna-Martinez 2010: 19-20) is still the best possibility for their chronological framework. It is noteworthy that the CSR and CSL dates strongly support a chronology of the last quarter of

\footnotetext{
"...the assemblage of metallic nodules with worked microstructures and tin contents similar to the artefacts suggests that these might be parts of artefacts or other metallurgical remains (e.g. seams and splashing droplets) gathered for recycling..." (Figueiredo et al. 2010b:1633)

6 These exemplars comprise (Senna-Martinez 2010: 19-20): one from CSR (CSR-A 7002 dated from 1312-1055 AC); two from CSL (CSL-2 and CSL-208I dated 1322-1007 AC); two from CSG (CSG-ME 122, dated 936-788 AC and another that was lost); one from Castelo dos Mouros (CMOUROS 123); and one from Cabeço do Cucão da Pedra Cavaleira (CCPC - Figueiredo et al. 2010). Their dating together with the more recent dating of the type exemplar from Roça do Casal do Meio (Vilaça and Cunha 2005: 52) suggest a period between $1200-800$ BC for their utilization, a dating that could be extended to encompass the $8^{\text {th }}$ century $B C$ if we take into consideration the recently published exemplars from Moita da Ladra (Valério et al. 2015b). The mainly Portuguese distribution of the type and specially its chronological implications are clearly overlooked in a recent synthesis (Gomá Rodríguez 2019).
} 
the second millennium $B C$ for the respective exemplars. This makes necessary, if we still insist in a Sicilian Cassibile III origin for the type (Gomá Rodríguez 2019: 81), a very quick Western Iberia diffusion of the model. Chemical compositional of the exemplars from CSR, CSL and CCPC, as well as from several of the wire fragments from several other sites, strongly suggest a local production, copying the Mediterranean prototypes as verified for the artefacts of Atlantic typology.

We once thought that the apogee of the CSGB site in the first quarter of the first millennium $B C$ could be linked to the Phoenician "port of trade" of Santa Olaia, in the lower Mondego (Senna-Martinez - Pedro 2000a: 67 and Fig. 5), the dating of the Phoenician establishment from the $7^{\text {th }}-6^{\text {th }}$ centuries BC (Arruda 1999-2000) made it impossible.

Alternatively the CSGB metal production (encompassing local production and eventual hoarding of regional surpluses - Senna-Martinez 2011: 288-290) and the Baiões/Santa Luzia area early Mediterranean connexions could still be related to the coast and contacts there, either by land via the Portuguese Extremadura, or also of maritime pre-colonial type. But yet another explanation could rely on a Beira Interior and lower Tagus basin connexion, through what we have been calling the "stelae route" (Senna-Martinez 2010; 2013a; 2013b).

The importance of this inland route for an early relationship with the Mediterranean gets reinforced through the presence in the two Portuguese Beiras, but mainly in Beira Interior, of the first irons (mostly small knives) that represent the largest concentration of these artefacts in Western Iberia (28 exemplars, dating from between 1293-890 cal BC -Vilaça 2008: 150; Reprezas 2010). Reaching the Tagus valley, in the south of Beira Interior, contacts could either proceed to the littoral and the sea - the LBA site of Quinta do Marcelo in the river lower estuary provided also evidence of early irons (Barros 2000; Senna-Martinez 2000) - or inland through the Spanish Estremadura and Andalucía to the southern tip of Iberia.

The only metallurgical technique of non-Atlantic origin, also with an East Mediterranean origin, we find in Baiões / Santa Luzia culture group is gilding by thermo-diffusion applied to an ornamental copper nail from CSR (Figueiredo et al. 2010a).
Of particular importance for the discussion on these early Mediterranean contacts in the Portuguese Beiras LBA are the bronze weights with known exemplars in CSGB, CSL and Canedotes (CAN) - in the area of Baiões / Santa Luzia culture group - as well as in the sites of Monte do Trigo and Moreirinha - in the LBA culture group of Beira Interior. The connexion of the exemplars of CSGB with the Cypriot and Aegean metric systems and the ones from CAN with Levantine (Phoenician-Canaanite) system (Vilaça 2003: 466-468) raise the question of their role in a socioeconomic environment of little or none goods circulation and mainly domestic forms of production (Senna-Martinez - Luís 2016).

A probable answer to the above question could be that these early meridional elements testify to pre-Phoenician efforts to reach the Portuguese Beiras areas rich in alluvial gold and tin (Senna-Martinez 2011).

The beginning of the LBA - in the last quarter of the second millennium BC - will see, all around lberia, the generalization of binary bronze production. For this to happen the critical resource would be tin (Senna-Martinez 2013b), as this technological change supposes the possibility of regular access (even in a small scale) to tin ore.

As one of us argued before (Senna-Martinez 2013b) this metal is easily available, under the form of cassiterite (tin oxide), in the alluvial placers found throughout the Portuguese Beiras up to Galicia in Northwest Iberia. Return LBA Andalucía Mediterranean connexions with the Tagus basin and Beira Interior - and even with the Baiões / Santa Luzia area - can be represented also by the arrival in these interior areas of stroke-burnish pottery decoration. But this would be reversed if we accept Jessica Reprezas (2010: 105-109) hypothesis that in Baiões/Santa Luzia and Beira Interior areas stroke-burnish pottery decoration precedes the cases found in Andalucía. However, even if this last situation is true, we find ourselves with another link southwards from the Portuguese Beiras.

We find probable that the Mediterranean pre-Phoenician influences in the Portuguese Beiras are linked to tin procurement from Mediterranean prospectors possibly originating either from Southern Iberia, through the "stele route", or the lower Tagus and Mondego's estuaries, the first one also with an easy link to that inland route (Senna-Martinez 2011). 
The development of the "port of trade" of Santa Olaia ( $7^{\text {th }}$ and $6^{\text {th }}$ centuries BC - cf. Arruda 1999-2000) and eventually also of Santarém ( $8^{\text {th }}-6^{\text {th }}$ centuries) can be seen as Phoenician tentative to access the interior gold and tin producing areas of the Portuguese Beiras. However we lack evidence that allow us to assume any success to this endeavor.

In the case of the Baiões / Santa Luzia culture group the only physical evidence for contact with EIA materialities are a double resort fibula - dated between 814-777 BC (Senna-Martinez 2000) - and a few pottery fragments ${ }^{7}$ of an orientalizing beige pottery vessel from COCB. Convergent with this lack of success is the fact that Santa Olaia developed its own metal producing capabilities (probably iron - Arruda 1999-2000: 238-239).

In what concerns the Beira Interior group, only in its southern part and in one only site close to the Tagus river - Cachouça (Vilaça - Basílio 2000; Vilaça 2007: 70-74) - is there any evidence that "...part of the eastern [artefactual] "package" has penetrated it..." (Vilaça - Arruda 2004: 11) demonstrating a link to the area of the river estuary. About the Beira Interior cultural group, both the above mentioned authors recognize that "...this indigenous world, more inland and removed from the 'peripheries' of Tartesos, is marked by ancestral connections to the more northern, Atlantic and Meseta worlds, which remain [during the EIA]..." (Vilaça - Arruda 2004: 24).

We think that what makes the major difference between the Phoenician "ports of trade" and the inland LBA communities is of a development and civilizational nature. Basically different "ways of producing" and of economic scale separate these two worlds. The urban and mercantile Phoenician, or Phoenician influenced settlements, have raw-material needs that are far bigger than what the small scale enterprises of the indigenous LBA communities could provide for. One big contrast resides exactly in metal production. Comparison between two case studies will suffice to demonstrate our point:

(1) CSGB metal (mainly bronze) production, even assuming that all the metal found during its excavations was produced there, is very small and estimated

Statistically nonsignificant considering the thousands of hand-made pottery sherds recovered in excavation. at less the $6 \mathrm{~kg} /$ year, while other culturally close archaeological sites would have still smaller productions (Senna-Martinez 2005). The actual direct evidence of bronze production at CSGB is limited to a slag fragment ${ }^{8}$ and twelve reduction prills (Figueiredo et al. 2010b); (2) Otherwise, the excavations of the Phoenician site of la Fonteta produced 422 exemplars of tuyères as well as tons of metallurgical dumps (Renzi 2007; 2012).

Returning to our main area of concern, the Mondego basin, we think that the establishment and location of Santa Olaia, a Phoenician EIA settlement that dominates the Mondego's palaeoestuary, probably implies interest in the metals from the hinterland. Its chronology as a port of trade (from the end of the $8^{\text {th }}$ century BC to the $6^{\text {th }}$ - Arruda 1999-2000: 254,258 ) is too late as to link it to the main phase of the Baiões/Santa Luzia culture group development $\left(13^{\text {th }}-10^{\text {th }}\right.$ centuries BC Senna-Martinez 2010: Table 1).

The failure of Santa Olaia to meet the metal revenue expectations of its founders probably was compensated by the development - already mentioned of its own local capability for iron producing (Arruda 1999-2000: 238-239) that can be also interpreted as a clear indication of the shortcomings of metal flux from more inland areas. The proto-urban nature of Santa Olaia together with what we can call the Phoenician "way of production" could have led, probably with the assistance of its littoral clients (for example the sites of Crasto de Tavarede and Conimbriga - Correia 1993; Arruda 1999-2000: 244- 245), to slaves capture in the hinterland (Wagner - Ruiz Cabrero 2015), thus destabilizing and eventually contributing to the collapse (in the $7^{\text {th }}$ century $\mathrm{BC}$ ?) of Baiões/Santa Luzia culture group inland settlements.

\footnotetext{
"... The presence of a slag fragment gives evidences for the local production of bronze - and this happens for the first time in the studied region - offering new expectations to the early proposals of a local exploration of ores, as cassiterite. Also, it suggests that smelting was still performed inside the settlement, similarly to what happened in earlier periods in the Iberian Peninsula, and differing from what happened in many contemporaneous LBA metallurgical sites in more Eastern/Mediterranean territories where smelting was done exclusively at the vicinity of the mine. The analysis of the slag fragment suggests smelting of copper ores with cassiterite or metallic tin by a rather primitive smelting process (as in a reaction vessel / crucible) leading to incomplete ore reduction and resulting in a heterogeneous microstructure with fine grained mixture of different phases. The low Fe content $(<0.05 \%)$ in the analyzed bronze artefacts does also point out to their fabrication in this kind of primitive smelting technology..." (Figueiredo et al. 2010b: 1632)
} 


\section{References}

ALARCÃO, J. (1988) - O Domínio Romano em Portugal. Mem Martins.

ARMBRUSTER, B. R. (2000) - Goldschmiedekunst und Bronzetechnik. Studien zum Metallhandwerk der Atlantichen Bronzezeit aufder Iberischen Halbinsel. Montagnac (Monographies instrumentum, 15).

ARMBRUSTER, B. R. (2002-2003) - A metalurgia da Idade do Bronze Final Atlântico do castro de Nossa Senhora da Guia, de Baiões (S. Pedro do Sul, Viseu). Estudos Pré-Históricos. 10-11, 145-155.

ARRUDA, A. M. (1999/2000) - Los fenicios en Portugal: Fenicios y mundo indígena en el centro y sur de Portugal (siglos VIII-VI a.C.). Barcelona (Cuadernos de Arqueología Mediterránea, 5-6).

BARON, J. - MIAZGA, B. - NOWAK, K. (2014) - Functions and contexts of Bronze Age metal casting moulds from Poland. Bulletin de la Société Préhistorique Française. 11 (2), 325-338.

BARROS, L. (2000) - O Fim do Bronze e a Idade do Ferro no Território de Almada. MA thesis in Archaeology. University of Lisbon.

BOTTAINI, C. - VILAÇA, R. - MONTERO RUIZ, I. (2004) - Metalurgia arcaica no concelho do Fundão (Beira Interior, Portugal). Uma abordagem analítica. In VILAÇA, R. (ed.) - II Congresso Internacional de Arqueologia da Região de Castelo Branco nos 100 anos da Sociedade dos Amigos do Museu de Francisco Tavares Proença Júnior. Castelo Branco, 179-188.

CANHA, A. J. (2002) - Canedotes: Povoado do Bronze Final do Alto Paiva. MA Thesis in Archaeology. Oporto University.

CHAPMAN, R. (1981) - Emergence of formal disposal areas and the «problem» of megalithic tombs in prehistoric Europe. In CHAPMAN, R. - KINNES, I. - RANDSBORG, K. (eds.) The Archaeology of Death. Cambridge, 71-81.

COATES, J. (2006) - Interpretation of Infrared Spectra, A Practical Approach. In Encyclopedia of Analytical Chemistry, 1-23. DOI: $10.1002 / 9780470027318$

COFFYN, A. (1985) - Le Bronze final atlantique dans la Péninsule Ibérique. Paris.

COMENDADOR, B. - FIGUEIREDO, E. - FONTE, J. - MEUNIER, E. (2014) - La primera minería y metalurgia del estaño en la Península Ibérica: aportaciones al estado de la cuestión. In Actas del XV Congreso Internacional Sobre Patrimonio Geológico y Minero. XIX Sesión Científica de SEDPGYM. Logrosán, 21-40.

COMENDADOR, B. - MEUNIER, E. - FIGUEIREDO, E. - LACKINGER, A. - FONTE, J. - FERNÁNDEZ FERNÁNDEZ, C. - LIMA, A. - MIRÃO, J. - SILVA, R.J.C. (2017) - Northwestern Iberian Tin Mining from Bronze Age to Modern Times: an overview. In NEWMAN, P. (ed.) - The Tinworking Landscape of Dartmoor in a European Context: Prehistory to 20th Century. Dartmoor, 133-153.

CORREIA, A. - SILVA, C. T. - VAZ, J. L. (1979) - Catalogo da Colecção Arqueológica Dr. José Coelho. Beira Alta. 38 (3), 605-638.

CORREIA, V. H. (1993) - Os materiais pré-romanos de Conimbriga e a presença fenícia no baixo vale do Mondego. Estudos Orientais. IV (Os Fenícios no Território Português), 229-283.

DAVEAU, S. (1980) - Espaço e tempo. Evolução do ambiente geográfico de Portugal ao longo dos tempos pré-históricos. Clio. Revista do Centro de História da Universidade de Lisboa. 2, 13-37.

DIAS, J. M. A. (1998) - Dinâmica sedimentar e evolução recente da plataforma continental portuguesa setentrional. Tese de Doutoramento, Lisboa.

EARLE, T. (2002) - Bronze Age Economics. Cambridge (Mass.).

FIGUEIREDO, E. (2010) - A study on metallurgy and corrosion of ancient copper-based artefacts from the Portuguese territory. Doctoral Thesis, Lisbon.
FIGUEIREDO, E. - ARAÚJO, M. F. - SILVA, R. J. C. - SENNA-MARTINEZ, J. C. - VAZ, J. L. I. (2011) - Characterisation of Late Bronze Age large size shield nails by EDXRF, micro-EDXRF and X-ray digital radiography. Applied Radiation and Isotopes. 69, 1205-1211.

FIGUEIREDO, E. - BOTTAINI, C. - MIGUEL, C. - LACKINGER, A. COSTA, S. - MIRÃO, J. - COMENDADOR REY, B. (2017) Integrated study of a Late Bronze Age axe mold by optical imaging, pXRF, SEM-EDS, XRD, $\mu \mathrm{FTIR}$ and $\mu$ Raman. Bilbao. TECHNART Conference. 2-6 May 2017.

FIGUEIREDO, E. - PEREIRA, M. A. S. - LOPES, F. - MARQUES, J. G. - SANTOS, J. P. - ARAÚJO, M. F. - SILVA, R. J. C. - SENNA-MARTINEZ, J. C. (2016) - Investigating Early / Middle Bronze Age Copper and Bronze Axes by Micro X-Ray Fluorescence Spectrometry and Neutron Imaging Techniques. Spectrochimica Acta Part B. 122, 15-22.

FIGUEIREDO, E. - SILVA, R. J. C. - ARAÚJO, M. F. - SENNA-MARTINEZ, J. C. (2010a) - Identification of ancient gilding technology and Late Bronze Age metallurgy by EDXRF, Micro-EDXRF, SEM-EDS and metallographic techniques. Microchimica Acta. 168, 283-291.

FIGUEIREDO, E. - SILVA, R.J.C. - SENNA-MARTINEZ, J. C. - ARAÚJO, M. F. - BRAZ FERNANDES, F. M. - INÊS VAZ, J. L. (2010b) Smelting and recycling evidences from the Late Bronze Age habitat site of Baiões (Viseu, Portugal). Journal of Archaeological Science. 37, 1623-1634.

GARCIA, F. (ed.) (1963) - Minas concedidas no Continente desde Agosto de 1836 a Dezembro de 1962. Lisboa.

GARCÍA-VUELTA, O. - CUESTA-GÓMEZ, F. - GALÁN DOMINGO, E. - MONTERO-RUIZ, I. (2014) - Los moldes de fundición de bronce para hachas de talón de La Macolla (Linares de Riofrío, Salamanca). Nuevos datos sobre viejos hallazgos. Zephyrus. LXXIV, 117-141.

GEIRINHAS, F. - GASPAR, M. - SENNA-MARTINEZ, J. C. - FIGUEIREDO, E. - ARAÚJO, M. F. - SILVA, R. J. C. (2011) - Copper isotopes on artifacts from Fraga dos Corvos First Bronze Age habitat site and nearby $C u$ occurrences: an approach on metal provenance. In MATA-PERELLÓ, M. - TORRO I ABAT, L. - FUENTES PRIETO, M. N. CAMPO, O., A. N. - PUCHA RIART, O. (eds.) - Actas del Quinto Congreso Internacional sobre mineria y metalurgia Históricas en el Suroeste Europeu. SeDPGYM. Léon, 177-184.

GIL, F. B. - SENNA-MARTINEZ, J. C. - GUERRA, M. F. - SERUYA, A. I. FABIÃO, C. (1989) - Produções metalúrgicas do Bronze Final do Cabeço do Crasto de S. Romão, Seia: uma primeira analise. In Actas do I Colóquio Arqueológico de Viseu. Viseu, 235-248.

GOMÁ RODRÍGUEZ, J. L. (2019) - Origin and sequence of the earliest fibulæ in the Iberian Peninsula. Cuadernos de Prehistoria y Arqueología de la Universidad Autónoma de Madrid. 45, 67-110.

IRUG - Infrared \& Raman Users Group; http:/ / www.irug. org / search-spectral-database?reset=Reset, Retrived on 28 February 2020.

JANSSEN, C. R. (1985) - História da vegetação. In DAVEAU, S. (ed.) - Livro-Guia da Pré-Reunião. Glaciação da Serra da Estrêla Aspectos o Quaternário da Orla Atlântica. G.T.P.E.Q.-G.E.T.Q. Lisboa, 66-72.

JANSSEN, C. R. - WOLDRINGH, R. E. (1981) - A preliminary radiocarbon dated pollen sequence from the Serra da Estrela, Portugal. Finisterra. XVI: 32, 299-309.

KIENLIN, T. L. (2013) - Copper and Bronze: Bronze Age Metalworking in Context. In FOKKENS, H. - HARDING, A. (eds.) - The Oxford Handbook of the European Bronze Age. Oxford, 414-436. 
KNAAP, W. O. V. - JANSSEN, C. R. (1991) - Utrecht on the Rocks Serra da Estrela (Portugal). XV Peat Excursion of the Syst. -Geobo. Institute, University of Bern, Part II. Laboratory of Paleobotany and Palynology. Utrecht, 14-21.

KNAAP, W. O. V. - VAN LEEUWEN, J. F. N. (1994) - Holocene vegetation, human impact, and climatic change in the Serra da Estrela, Portugal. In LOTTER, A. F. - AMMANN, B. (eds.) Festschrift Gerhard Lang (Dissertationes Botanicae, 234.), 497-535.

MARTINS, A. F. (1940) - O Esforço do Homem na Bacia do Mondego. Coimbra.

Mineralogy Database, http://webmineral.com/, Retrieved on 28 February 2020.

OLIVEIRA, A. (1972) - A Vida Económica e Social de Coimbra de 1537 a 1640, Volume II, Coimbra.

PARE, C. (2000) - Bronze and the Bronze Age. In PARE, C. (ed.) Metals Make the World Go Round. Oxford, 1-38.

RADIVOJEVIĆ, M. - ROBERTS, B. W. - PERNICKA, E. - STOS-GALE, Z. MARTINÓN-TORRES, M. - REHREN, T. - BRAY, P. - BRANDHERM, D. - LING, J. - MEI, J. - VANDKILDE, H. - KRISTIANSEN, K. SHENNAN, S. J. - BROODBANK, C. (2019) - The Provenance, Use, and Circulation of Metals in the European Bronze Age: The State of Debate. Journal of Archaeological Research. 27, 131-185.

RENFREW, C. - CHERRY, J. F. (eds.) (1986) - Peerpolity interaction and socio-political change. Cambridge.

RENZI, M. (2007) - Estudio Tipológico y Funcional de las Toberas del Yacimiento de La Fonteta. Trabajos de Prehistoria. 64 (1), 165-177.

RENZI, M. (2012) - La Fonteta (Guardamar del Segura, Alicante) y la metalurgia fenicia de época arcaica. PhD Thesis. Complutense University of Madrid.

REPREZAS, J. L. (2010) - A cerâmica decorada do "Mundo Baiões/ Santa Luzia". Lisbon. MA Thesis. University of Lisbon.

ROVIRA LLORENS, S. - MONTERO RUIZ, I. (2013) - Iberia: Technological Development of Prehistoric Metallurgy. In BURMEISTER, S. - HANSEN, S. - KUNST, M. - MÜLLER-SCHEESSEL, N. (eds.) - Metal Matters; Innovative Technologies and Social Change in Prehistory and Antiquity. Rahden/Westf. Leidorf, 231-239.

SENNA-MARTINEZ, J. C. (1994) - Entre Atlântico e Mediterrâneo: algumas reflexões sobre o Grupo Baiões/Santa Luzia e o desenvolvimento do Bronze Final peninsular. Trabalhos de Arqueologia da EAM. 2, 205-222.

SENNA-MARTINEZ, J. C. (1995-1996) - Pastores, recolectores e construtores de megálitos na Plataforma do Mondego no IV e III milénios AC: (1) O sítio de Habitat do Ameal-VI. Trabalhos de Arqueologia da EAM. 3/4, 83-122.

SENNA-MARTINEZ, J. C. (1999) - The central Portugal Late Bronze Age: Contribution to a study on regional ethnogenesis. Estudos do Quaternário. 2, 41-50.

SENNA-MARTINEZ, J. C. (2000) - O problema dos primeiros ferros peninsulares em contextos do Bronze Final da Orla Atlântica: os dados do "Outeiro dos Castelos de Beijos" (Carregal do Sal). Trabalhos de Arqueologia da EAM. 6, 41-58.

SENNA-MARTINEZ, J. C. (2005) - O outro lado do comércio orientalizante: Aspectos da produção metalúrgica no polo indígena, o caso das Beiras Portuguesas. In CELESTINO PÉREZ, S. - JIMÉNEZ ÁVILA, J. (eds.) - Actas del III Simposio Internacional de Arqueología de Mérida: Protohistoria del Mediterráneo Occidental. Mérida/Madrid, 901-910.
SENNA-MARTINEZ, J. C. (2010) - "Um mundo entre mundos". O grupo Baiões / Santa Luzia, sociedade, metalurgia e relações inter-regionais. Iberografias. 6, 13-26.

SENNA-MARTINEZ, J. C. (2011) - La «conexión lusitana»: contactos orientalizantes y búsqueda de estaño y oro en el Centro-Norte portugués. In DOMíNGUEZ PÉREZ, J. C. (ed.) - Gadir y el Círculo del Estrecho revisados. Propuestas de la arqueología desde un enfoque social. Cádiz, 285-296.

SENNA-MARTINEZ, J. C. (2013a) - Um rio na(s) rota(s) do estanho: O Tejo entre a Idade do Bronze e a Idade do Ferro. CIRA Arqueologia. 2, 7-18.

SENNA-MARTINEZ, J. C. (2013b) - Metals, Technique and Society. The Iberian Peninsula between the first Peasant Societies with Metallurgy and the "Urban Revolution". In GUERRA M. F. - TISSOT, I. (eds.) - A Ourivesaria Pré-Histórica do Ocidente Peninsular Atlântico. Compreender para Preservar. Lisboa (Projecto AuCORRE), 11-20.

SENNA-MARTINEZ, J.C. (2013c) - Aspectos do Centro-Norte do Ocidente Peninsular no Final da Idade do Bronze: Povoamento, Metalurgia e Sociedade. Estudos Arqueológicos de Oeiras. 20, 173-190.

SENNA-MARTINEZ, J. C. - FIGUEIREDO, E. - ARAÚJO, M. F. - SILVA, R. J. C. - VALÉRIO, P. - VAZ, J. L. I. (2011) - Metallurgy and Society in "Baiões / Santa Luzia" Culture Group: Results of the METABRONZE Project. In MARTINS, C. B. - BETTENCOURT, A. M. S. - MARTINS, J. I. F. P. - CARVALHO, J. (eds.) - Settlement and Mining in the Atlantic Western Europe. Proceedings of the First International Congress. Braga, 409-425.

SENNA-MARTINEZ, J. C. - GARCIA, M. F. - ROSA, M. J. (1984) Contribuições para uma tipologia da olaria do megalitismo das Beiras: olaria da Idade do Bronze (I). Clio/Arqueologia. 1, 105-138.

SENNA-MARTINEZ, J. C. - LUÍS, E. (2016) - Technique and Social Complexity: Development Trajectories of Peasant Societies with Metallurgy during the Bronze Age of Western Iberia. In SOARES, J. (ed.) - Social complexity in a long term perspective. Proceedings of Session B15 of UISPP $17^{\text {th }}$ Congress. Setúbal, 115-130.

SENNA-MARTINEZ, J. C. - NASCIMENTO, A. Q. - CARVALHO, A. F. ALMEIDA, F. (1993) - A ocupação do Bronze Final do Cabeço do Cucão, Pedra Cavaleira (Silgueiros, Viseu): uma primeira análise. Trabalhos de Arqueologia da EAM. 1, 143-147.

SENNA-MARTINEZ, J. C. - PEDRO, I. (2000a) - Between Myth and Reality: the foundry area of Senhora da Guia de Baiões and Baiões / Santa Luzia Metallurgy. Trabalhos de Arqueologia da EAM. 6, 61-77.

SENNA-MARTINEZ, J. C. - PEDRO, I. (2000b) - O «Grupo Baiões / Santa Luzia» no Quadro do Bronze Final do Centro de Portugal. In SENNA-MARTINEZ, J. C. - PEDRO, I. (eds.) Por Terras de Viriato: Arqueologia da Região de Viseu. Viseu, 119-131.

SENNA-MARTINEZ, J. C. - PEDRO, I. (eds.) (2000) - Por Terras de Viriato: Arqueologia da Região de Viseu. Viseu.

SENNA-MARTINEZ, J. C. - VENTURA, J. M. Q. (2008) - Do mundo das sombras ao mundo dos vivos: Octávio da Veiga Ferreira e o megalitismo da Beira Alta, meio século depois. Estudos Arqueológicos de Oeiras. Homenagem a Octávio da Veiga Ferreira. 16, 317-350.

SILVA, A. C. F. - SILVA, C. T. - LOPES, A. B. (1984) - Depósito de fundidor do final da Idade do Bronze do castro da Senhora da Guia (Baiões, S. Pedro do Sul, Viseu). Lucerna. Extra, 73-95. 
SILVERSTEIN, R. M. - BASSIER, G. C. - MORRIL, T. C. (1983) Spectrometric Identification of Organic Compounds.

SOARES, A. M. M. - VALÉRIO, P. - FRADE, J. C. - OLIVEIRA, M. J. PATOILO, D. - RIBEIRO, I. - AREZ, L. - SANTOS, F. J. C. - ARAÚJO, M. F. (2009) - A Late Bronze Age Stone mould for flat axes from Casarão da Mesquita 3 (São Manços, Évora, Portugal). In CRADDOCK, P.T. - GIUMLIA-MAIR, A. - HAUPTMANN, A. (eds.) $-2^{\text {nd }}$ International Conference Archaeometallurgy in Europe. Selected Papers. Milan, 145-157.

TEIXEIRA, C. C. (1939-42) - Molde de fundição para machados de bronze de duplo anel. Trabalhos da Sociedade Portuguesa de Antropologia e Etnologia. 9, 126-130.

Thermo Scientific ${ }^{\mathrm{TM}}$ Nicolet $^{\mathrm{TM}}$ FTIR Spectral Library, OMINIC software 9.2.98, 2012.

VALÉRIO, P. - ARAÚJO, M. F. - SENNA-MARTINEZ, J. C. - VAZ, J. L. I. (2006) - Caracterização química de produções metalúrgicas do Castro da Senhora da Guia de Baiões (Bronze Final). O Arqueólogo Português. Série IV, 24, 289-319.

VALÉRIO, P. - ARAÚJO, M. F. - SOARES, A. M. M. - SILVA, R. J. C. BAPTISTA, L. - MATALOTO, R. (2018) - Early imports in the Late Bronze Age of South-Western Iberia: the bronze ornaments of the hypogea at Monte da Ramada 1 (Southern Portugal). Archaeometry. 60 (2), 255-268.

VALÉRIO, P. - SILVA, R. J. C. - SOARES, A. M. M. - ARAÚJO, M. F. GONÇALVES, A. P. - SOARES, R. M. (2015a) - Combining X-ray based methods to study the protohistoric bronze technology in Western Iberia. Nuclear Instruments and Methods in Physics Research B. 358, 117-123.

VALÉRIO, P. - SOARES, A. M. - MONTEIRO, M. - PEREIRA, A. ARAÚJO, M. F. - SILVA, R. J. C. (2015b) - A Compositional and Microstructural Study of Eighth-Century BC Bronzes from Moita da Ladra (Tagus Estuary): How did the spread of the Phoenician Metallurgy take place in Western Iberia? Archaeometry. 58, 593-609.

VAN DEN BRINK, L. M. - JANSSEN, C. R. (1985) - The effect of human activities during cultural phases on the development of montane vegetation in the Serra da Estrela, Portugal. Review of Palaeobotany and Palynology. 44, 193-215.

VAZ, J. L. I. (2009) - Lusitanos no Tempo de Viriato - Quotidiano e Mito. Lisboa.
VENTURA, J. M. Q. (2018) - Núcleo Megalítico dos Fiais-Azenha (Carregal do Sal, Portugal): um balanço. In SENNA-MARTINEZ, J. C. - DINIZ, M. - CARVALHO, A. F. (eds.) - De Gibraltar aos Pirenéus. Megalitismo, Vida e Morte na Fachada Atlântica Peninsular. Lapa do Lobo (Nelas), 51-63.

VILAÇA, R. (1995) - Aspectos do povoamento da Beira Interior (Centro e Sul) nos finais da Idade do Bronze. Lisboa (Trabalhos de Arqueologia 9. 2 Vols).

VILAÇA, R. (1997) - Metalurgia do Bronze Final da Beira Interior: Revisão dos dados à luz de novos resultados. Viseu. Estudos Pré-Históricos. V, 123-154.

VILAÇA, R. (2003) - Acerca da existência de ponderais em contextos do Bronze Final/Ferro Inicial no território português. O Arqueólogo Português. Série IV, 21 (4), 245-288.

VILAÇA, R. (2004) - Metalurgia do Bronze Final no entre Douro e Tejo português: contextos de produção, uso e deposição. In PEREA, A. (ed.) - Actas del Congreso: Ámbitos Tecnológicos, Ámbitos de Poder. La Transición Bronce Final-Hierro en la Península lbérica. Madrid, 1-12.

VILAÇA, R. (2007) - A Cachouça (Idanha-a-Nova, Castelo Branco). Construção e organização de um caso singular de inícios do I milénio AC. In Actas do IV Congresso de Arqueologia Peninsular. Faro, 67-75.

VILAÇA, R. (2008) - Através das Beiras. Pré-História e Proto-História. Coimbra.

VILAÇA, R. - ARRUDA, A. M. (2004) - Ao longo do Tejo, do Bronze ao Ferro. Conimbriga. 43, 11-45.

VILAÇA, R. - BASÍLIO, L. (2000) - Contributo para a caracterização arqueológica da I Idade do Ferro da Beira Interior: cerâmicas a torno da Cachouça (Idanha-a-Nova). Al-madan. II série, 9, 39-47.

VILAÇA, R. - CUNHA, E. (2005) - A Roça do Casal do Meio (Calhariz, Sesimbra): novos contributos. Al-Madan. II Série, 13, 48-57.

WAGNER, C. G. - RUIZ CABRERO, L. A. (2015) - La mano de obra rural en los asentamientos fenicios de Occidente. In ZURBACH, J. (ed.) - La main-d'oeuvre agricole en Méditerranée archaïque, Statuts et dynamiques économiques. Bordeaux (Ausonius Scripta Antiqua, 73), 85-107.

WEBLEY, L. - ADAMS, S. (2016) - Material genealogies: Bronze moulds and their castings in Later Bronze Age Britain. Proceedings of the Prehistoric Society. 82, 323-340. 

AVALIADORES OPHIUSSA (2018-2020)

Adolfo Fernández Fernández

Ahmed Mcharek

Albert Ribera i Lacomba

Álvaro Gómez Peña

Amílcar Guerra

Ana Cristina Martins

Ana Delgado Hervás

Ana Margarida Arruda

Ana Maria Niveau de Villedary y Mariñas

António Faustino Carvalho

António Carlos Valera

Carlos P. Odriozola

Carlos Pereira

Cátia Mourão

Catarina Costeira

Catarina Viegas

Corina Liesau

Elisa Garcia Prosper

Elisa Guerra Doce

Enrique García Vargas

Ernst Pernicka

Esther Rodríguez González

Francisco B. Gomes

Francisco J. Núñez

F. Germán Rodríguez Martín

Javier Jiménez Ávila

Javier Mangado Llach

Jesús Acero Pérez

João Pedro Bernardes

João Senna-Martinez
João Luís Cardoso

Joaquina Soares

José Carlos Quaresma

José Clemente Martin de la Cruz

José Ruivo

Juan Antonio Cámara Serrano

Leonardo García Sanjuán

Luís Araújo

Luís Raposo

Macarena Bustamante

Maria João Valente

Maria José de Almeida

Mariano Torres Ortiz

Mário Jorge Barroca

Marta Moreno García

Mounir Fantar

Patrícia Matos

Raquel Vilaça

Ricardo Costeira da Silva

Roberto Risch

Rodrigo Banha da Silva

Rui Gomes Coelho

Rui Martiniano

Rui Morais

Sergio Escribano Ruiz

Sérgio Gomes

Simon Davis

Tomás Cordero Ruiz

Victor S. Gonçalves 


\section{POLÍTICA EDITORIAL}

A Ophiussa - Revista do Centro de Arqueologia da Universidade de Lisboa foi iniciada sob a direcção de Victor S. Gonçalves em 1996, tendo sido editado o volume 0. O volume 1 (2017) é uma edição impressa e digital da UNIARQ - Centro de Arqueologia da Universidade de Lisboa.

O principal objectivo desta revista é a publicação e divulgação de trabalhos com manifesto interesse, qualidade e rigor científico sobre temas de Pré-História e Arqueologia, sobretudo do território europeu e da bacia do Mediterrâneo.

A Ophiussa - Revista do Centro de Arqueologia da Universidade de Lisboa publicará um volume anual. A partir de 2018, os artigos submetidos serão sujeitos a um processo de avaliação por parte de revisores externos (peer review). O período de submissão de trabalhos decorrerá sempre no primeiro trimestre e a edição ocorrerá no último trimestre de cada ano.

A revista divide-se em duas secções: artigos científicos e recensões bibliográficas. Excepcionalmente poderão ser aceites textos de carácter introdutório, no âmbito de homenagens ou divulgações específicas, que não serão submetidos à avaliação por pares. Isentas desta avaliação estão também as recensões bibliográficas.

Todas as submissões serão avaliadas, em primeira instância, pela Coordenação Editorial, no que respeita ao seu conteúdo formal e à sua adequação face à política editorial e às normas de edição da revista. Os trabalhos que cumprirem estes requisitos serão posteriormente submetidos a um processo de avaliação por pares cega / blind peer review (mínimo de dois revisores). O Conselho Científico, constituído pela direcção da UNIARQ e por investigadores externos, acompanhará o processo de edição.

Esta etapa será concretizada por investigadores externos qualificados, sendo os respectivos pareceres entregues num período não superior a três meses. Os revisores procederão à avaliação de forma objectiva, tendo em vista a qualidade do conteúdo da revista; as suas críticas, sugestões e comentários serão, na medida do possível, construtivos, respeitando as capacidades intelectuais do(s) autor(es). Após a recepção dos pareceres, o(s) autor(es) tem um prazo máximo de um mês para proceder às alterações oportunas e reenviar o trabalho.

A aceitação ou recusa de artigos terá como únicos factores de ponderação a sua originalidade e qualidade científica. O processo de revisão é confidencial, estando assegurado o anonimato dos avaliadores e dos autores dos trabalhos, neste último caso até à data da sua publicação.

Os trabalhos só serão aceites para publicação a partir do momento em que se conclua o processo da revisão por pares. Os textos que não forem aceites serão devolvidos aos seus autores. O conteúdo dos trabalhos é da inteira respon- sabilidade do(s) autor(es) e não expressa a posição ou opinião do Conselho Científico ou da Coordenação Editorial. A Revista Ophiussa segue as orientações estabelecidas pelo Commitee on Publication Ethics (COPE, Comité de Ética em Publicações): https://publicationethics.org/.

O processo editorial decorrerá de forma objectiva, imparcial e anónima. Erros ou problemas detetados após a publicação serão investigados e, se comprovados, haverá lugar à publicação de correções, retratações e/ou respostas. As colaborações submetidas para publicação devem ser inéditas. As propostas de artigo não podem incluir qualquer problema de falsificação ou de plágio. Para efeito de detecção de plágio será utilizada a plataforma URKUNDU (https:// www.urkund.com/pt-br/).

As ilustrações que não sejam do(s) autor(es) devem indicar a sua procedência. O Conselho Científico e a Coordenação Editorial assumem que os autores solicitaram e receberam autorização para a reprodução dessas ilustrações, e, como tal, rejeitam a responsabilidade do uso não autorizado das ilustrações e das consequências legais por infracção de direitos de propriedade intelectual.

É assumido que todos os Autores fizeram uma contribuição relevante para a pesquisa reportada e concordam com o manuscrito submetido. Os Autores devem declarar de forma clara eventuais conflitos de interesse. As colaborações submetidas que, direta ou indiretamente, tiveram o apoio económico de terceiros, devem claramente declarar essas fontes de financiamento.

Os textos propostos para publicação devem ser inéditos e não deverão ter sido submetidos a qualquer outra revista ou edição electrónica. Aceitam-se trabalhos redigidos em português, inglês, espanhol, italiano e francês.

Esta edição disponibiliza de imediato e gratuitamente a totalidade dos seus conteúdos, em acesso aberto, de forma a promover, globalmente, a circulação e intercâmbio dos resultados da investigação científica e do conhecimento.

A publicação de textos na Ophiussa - Revista do Centro de Arqueologia da Universidade de Lisboa não implica o pagamento de qualquer taxa nem dá direito a qualquer remuneração económica.

Esta publicação dispõe de uma versão impressa, a preto e branco, com uma tiragem limitada, que será distribuída gratuitamente pelas bibliotecas e instituições mais relevantes internacionalmente, e intercambiada com publicações periódicas da mesma especialidade, que serão integradas na Biblioteca da Faculdade de Letras da Universidade de Lisboa. Conta, paralelamente, com uma versão digital, a cores, disponibilizada no endereço www.ophiussa.letras.ulisboa.pt, onde se pode consultar a totalidade da edição.

Para mais informações: ophiussa@letras.ulisboa.pt 


\section{EDITORIAL POLICY}

Ophiussa - Revista do Centro de Arqueologia da Universidade de Lisboa started in 1996, with the edition of volume 0 . From 2017, this journal is a printed and digital edition of UNIARQ - Centro de Arqueologia da Universidade de Lisboa.

The main objective of this journal is the publication and dissemination of papers of interest, quality and scientific rigor concerning Prehistory and Archeology, mostly from Europe and the Mediterranean basin.

Ophiussa - Revista do Centro de Arqueologia da Universidade de Lisboa will publish an annual volume. From 2018, submitted articles will be subject to a peer-review evaluation process. The submission period will always occur in the first quarter of each year and the edition will occur in the last quarter.

The journal is divided into two sections: scientific articles and bibliographic reviews. Exceptionally, texts of an introductory nature may be accepted, in the context of specific tributes or divulgations, which will not be submitted to peer-review evaluation. Exemptions from this evaluation are also the bibliographic reviews.

All submissions will be considered, in the first instance, by the Editorial Board, regarding its formal content and adequacy in face of the editorial policy and the journal's editing standards. Papers that meet these requirements will subsequently be submitted to a blind peerreview process (minimum of two reviewers). The Scientific Council, constituted by the directors of UNIARQ and external researchers, will follow the editing process.

This stage will be carried out by qualified external researchers, and their feedback will be delivered within a period of no more than two months. The reviewers will carry out the evaluation in an objective manner, in view of the quality and content of the journal; their criticisms, suggestions and comments will be, as far as possible, constructive, respecting the intellectual abilities of the author(s). After receiving the feedback, the author(s) has a maximum period of one month to make the necessary changes and resubmit the work.

Acceptance or refusal of articles will have as sole factors of consideration their originality and scientific quality. The review process is confidential, with the anonymity of the evaluators and authors of the works being ensured, in the latter case up to the date of its publication.

Papers will only be accepted for publication as soon as the peer review process is completed. Texts that are not accepted will be returned to their authors. The content of the works is entirely the responsibility of the author(s) and does not express the position or opinion of the Scientific Council or Editorial Board. The Journal Ophiussa follows the guidelines established by the Commitee on Publication Ethics (COPE, the Ethics Committee Publications): https:// publicationethics.org/
The editorial process will be conducted objectively, impartially and anonymously. Errors or problems detected after publication will be investigated and, if proven, corrections, retractions and / or responses will be published. Contributions submitted for publication must be unpublished. Article submissions can not include any problem of forgery or plagiarism. In order to detect plagiarism, the URKUNDU platform will be used.

Illustrations that are not from the author(s) must indicate their origin. The Scientific Council and Editorial Board assume that the authors have requested and received permission to reproduce these illustrations and, as such, reject the responsibility for the unauthorized use of the illustrations and legal consequences for infringement of intellectual property rights.

It is assumed that all Authors have made a relevant contribution to the reported research and agree with the manuscript submitted. Authors must clearly state any conflicts of interest. Collaborations submitted that directly or indirectly had the financial support of third parties must clearly state these sources of funding.

Texts proposed for publication must be unpublished and should not have been submitted to any other journal or electronic edition. Works written in Portuguese, English, Spanish, Italian and French are accepted.

The publication of texts in Ophiussa - Revista do Centro de Arqueologia da Universidade de Lisboa does not imply the payment of any fee nor does it entitle to any economic remuneration.

This edition immediately and freely provides all of its content, in open access, in order to promote global circulation and exchange of scientific research and knowledge. This publication has a limited printed edition in black and white, which will be distributed free of charge by the most relevant international libraries and institutions, and exchanged with periodicals of the same specialty, which will be integrated in the Library of Faculdade de Letras of Universidade de Lisboa. It also has a digital version, in color, available at address http://ophiussa.letras.ulisboa.pt, where one can consult the entire edition.

For more information contact: ophiussa@letras.ulisboa.pt 
REVISTA DO CENTRO DE ARQUEOLOGIA DA UNIVERSIDADE DE LISBOA

\section{$4-2020$}

ÍNDICE

The megalithic clusters of Deserto and Barrocal das Freiras

(Montemor-o-Novo, Middle Alentejo) in the building of the sacred

landscapes of ancient peasant societies of the $4^{\text {th }}$ and $3^{\text {rd }}$ millennia BCE

VICTOR S. GONÇALVES, MARCO ANTÓNIO ANDRADE

From aDNA to Archaeology: Genética da transição Calcolítico-Idade do Bronze

no Sul de Portugal

ANA CATARINA BASÍLIO

Foundry in the Late Bronze Age Baiões/Santa Luzia Cultural Group:

some reflections starting from a new metallic mould for unifacial palstaves

JOÃO CARLOS SENNA-MARTINEZ, PEDRO VALÉRIO, MARIA HELENA CASIMIRO,

LUÍS M. FERREIRA, MARIA DE FÁTIMA ARAÚJO, HORÁCIO PEIXOTO

O conjunto vítreo da necrópole da I Idade do Ferro da Fonte Velha

de Bensafrim (Lagos)

FRANCISCO B. GOMES

Espacios de almacenamiento y producción de la Turdetania.

Una reflexión más allá de los hornos

VIOLETA MORENO MEGÍAS

Os três sarcófagos etruscos da colecção de Sir Francis Cook

no Museu Arqueológico de São Miguel de Odrinhas (Sintra)

MARTA RIBEIRO, NUNO SIMÕES RODRIGUES

Nuevos datos para el conocimiento del suburbium del Municipum

Florentinum Iliberritanum (Granada): las recientes intervenciones

en el solar de Mondragones

ÁNGEL RODRÍGUEZ AGUILERA, MACARENA BUSTAMANTE-ÁLVAREZ,

JULIA RODRÍGUEZ AGUILERA, CARMEN JÓDAR HÓDAR, JOSÉ M. GARCÍA-CONSUEGRA FLORES

Mapear a bibliografia. Abordagem metodológica para a gestão

187

de dados bibliográficos

NATÁLIA BOTICA, SÍLVIA MACIEL, REBECA BLANCO-ROTEA

Recensões bibliográficas

(TEXTOS: JORGE DEL REGUERO GONZÁLEZ, LUIS MIGUEL CARRANZA PECO,

MARTA BERMÚDEZ CORDERO, ÁLVARO GÓMEZ PEÑA, ANDRÉ TEXUGO)

Da CAALG à UNIARQ: a génese do Centro de Arqueologia da Universidade

de Lisboa no quadro do sistema científico de meados dos anos 70

a meados dos anos 90 do século XX

ANDRÉ PEREIRA

Avaliadores Ophiussa (2018-2020) 